\title{
The application and efficiency of digital marketing strategies of life insurance market in Thailand
}

\author{
Napassorn Ittiprasert \\ The master degree of the Digital marketing program, Entrepreneurship \\ The University of the Thai Chamber of Commerce, Thailand
}

\begin{abstract}
Purpose: The proposed of this study is to explore digital marketing strategy used by leading life insurance company in Thailand by focusing on company website SEO analysis and the financial performance to identify how insurer digital marketing strategy work efficiently.

Design/ methodology/ approach: Data gathering and analysis, Netnographic

Finding: the results suggest that organization digital strategy strategy is depend on objective along with market positioning and deep understanding of competitive advantage of the firm technology capability, i.e. new product development in response to the behavior change, the service distribution channel, upgrading and transfer efficient communication are proposed.
\end{abstract}

Keywords: Life insurance, Digital marketing strategies, Search engines optimization, Thailand

Paper type: Research paper

\section{Chapter 1. Introduction}

\subsection{Introduction and problem statement}

In the 21st century, the financial service all around the world has received a series of changes through digitalization and globalization of economic development. These changes affect the insurance industry productivities, market structure, and sales performance efficiency ("Harness the Power of Digital in Life insurance", 2016). There occurred a relationship between digital strategy and business performance. The marketing concept established in the mid-1950s, the shortest definition of marketing is the one proposed by Kotler and Keller (2014) is "...meeting needs profitably". The business philosophy shifted to a customer-centric approach, finding the right product to sever your customer. Nowadays technology has become more common in human life, there are many knowledge developments by supporting technology. Developed in Digital marketing during the 1990s and 2000s, the last paternity concept of digital marketing is a form of direct marketing that links consumers with sellers electronically using interactive technologies like emails, websites, online forums and newsgroups, interactive television, mobile communications, etc. ("Definition of digital marketing", 2015 and "The Four Faces of Digital Marketing"). Currently, marketers use numerous digital tactics and channels to connect with customers where they spend much of their time online.

In 2019, approximately 50 million people had access to the internet in Thailand. This figure is projected to grow to about 61 million in 2025 ("Internet user penetration in Thailand 


\section{BEHAVIORAL \& SOCIAL SCIENCES}

July $23-25,2021$

Stockholm, Sweden

from 2017 to 2025", 2020). Digitalization trends have created new tools to develop innovative marketing strategies for this industry. Insurance companies are already taking advantage of the commercial potential. Due to the highly competitive environment, it's challenging for each player to differentiate from others and respond to the changing customer behaviors.

\section{Brief discuss of insurance industry in Thailand}

The life insurance market in Thailand has grown continuously. Based on past couple of years, 2011-2016 compound annual growth rate at 4.7\% CAGR larger than the world's CAGR at 3.3\% ("Economic Outlook Report", 2019). In 2020 the life insurance market is expected worth more than 800 billion baths. According to the data provided by the Thailand Insurance Institute in 2020, market share of the top 5 life insurance companies in Thailand were as follows.

1. AIA: One of the largest life insurance groups in the Asia Pacific, market share $23.47 \%$.

2. Thai Life Insurance: Local insurance company market share of $14.65 \%$.

3. FWD Insurance: In 2018 FWD acquired SCBLife, local insurance. The result is FWD taking a $14.11 \%$ market share

4. Muang Life Insurance: Local insurance company with a market share of $12.62 \%$.

5. Krungthai-AXA: The joint venture of a Krungthai bank and the AXA Group which is a leading life insurance business from Europe owned a market share of $9.24 \%$.

However, if compared with other countries that take advantage of the insurance, Thais still used a few insurances as risk management tools. Considering the proportion of insurance premiums per GDP of Thailand is equal to $5.80 \%$ while the insurance premiums per GDP of Japan and England are $10.80 \%$ and $10.60 \%$ percent respectively. In terms of life insurance policy holdings or insurance penetration rate, Thailand is only $37.77 \%$, while Japan has a life insurance policy holding more than $300 \%$. If compared with neighboring countries in the ASEAN region, it was found that insurance expenses or insurance density of Thais is 10,826 baht per head less than Singapore and Malaysia that worth 131,565 baht and 18,375 baht respectively ("Growth Credibility", 2016). These statistics reflect the growth opportunity in Thailand's life insurance market even though insurance companies have to educate the market along the way.

\subsection{Research objectives}

This independent study aims to study application and efficiency of digital marketing strategy of leading life insurance company in Thailand during 2020.

\subsection{Significance of the research}

Currently, online sale channels distribute insurance premium less than $3 \%$ of total receive premium on another hand, the consumers journey researching online buying offline (ROBO) is increasing. Together with Thailand is one of the countries with high internet user 


\section{$8^{\text {th }}$ International Conference on Research in}

\section{BEHAVIORAL \& SOCIAL SCIENCES}

July $23-25,2021$

Stockholm, Sweden

penetration rate $75 \%$ compared to the world average of 59\% (Statista, 2020). From Neilson research ("The Importance of an Effective Insurance Website", 2019), a well-designed website affects the reach and the credibility of the business which ultimately leads to sales. Therefore, I will focus on the company website which is the main channel for searching information of interested people. There will reflect how each insurer pays attention to the development of the company's digital strategy. Then will analyze the efficiency of the marketing activities.

\section{$1.4 \quad$ Research question}

1. What is the digital marketing strategy used by leading life insurers in Thailand?

2. To study the relationship between digital marketing strategy and return on marketing investment (ROMI)?

\subsection{Scope of the study}

The scope of the study is limited to gathering information from company websites by using website audit tools and observation between January 1, 2021 to February 28, 2021. For the target company are the top 5 life insurance companies in Thailand. The financial performance will be analyzed based on 3 years financial report during 2017-2019. To see efficiency of marketing activities.

\subsection{Expected benefit}

This study will analyze customer information seeking experience allowing insurance companies or interested people to understand the digital marketing strategies that leading insurers in Thailand applied to achieve business goals, as well as keep existing customers and attract new customers with minimal cost.

\subsection{Operation definition}

Digital marketing strategy in this research will focus on search engines optimization (SEO) and number of company's social medias follower

1. The SEO investigation are the following dimension:

i. Components and design of the website

ii. Information seeking in term of product and service

iii. Ranking of the website on Google search

iv. Audience behavior

2. To measure economic efficiency of marketing activities

i. Compare the financial ratio in 2020.

- Ratio of First Year Underwriting Expenses to Net First Year Premiums

- Ratio of Renewal Underwriting Expenses to Net Renewal Premiums

- Return on Equity\% (net profit/ equity $* 100)$

- Return on Asset \% (net profit/ asset *100) 


\section{$8^{\text {th }}$ International Conference on Research in}

\section{BEHAVIORAL \& SOCIAL SCIENCES}

July $23-25,2021$

Stockholm, Sweden

- Return on Investment Ratio

ii. Indicated the economic efficiency

- Return on Investment

- Return on Marketing Investment

$\begin{aligned} & \text { Return on Marketing } \\ & \text { Investment (ROMI) }\end{aligned}=\frac{\text { Incremental Revenue }}{\text { Marketing Cost }}$

Calculation definition:

Incremental revenue

$=$ First year premium + Single premium

$=$ New business premium

Marketing cost

$=$ Promotional expense + Advertising spending

- Invested Asset: Policy Reserve (Admitted Value)

\section{Chapter 2. Literature review}

\subsection{Theory and related research}

\section{Digital marketing}

Digital marketing is a form of direct marketing which links consumers with sellers electronically using interactive technologies like emails, websites, online forums and newsgroups, interactive television, mobile communications etcetera (Kotler and Armstrong, 2009). It facilitates many-to-many communications due to its high level of connectivity and is usually executed to promote products or services in a timely, relevant, personal and costeffective manner (Bains et al., 2011) Therefore, digital marketing encompasses all marketing efforts that use an electronic device or internet, (Desai, D. 2019, March). Digital marketing consists of several parts that cover consumer behavior in online platforms. Based on WebFX (Emily, 2020), 2nd rank on Google first Search Engine Result Page (SERP), there are 7 major components of a digital marketing plan include: search engine optimization (SEO), pay per click advertising (PPC), web design, content marketing, social media marketing, email marketing, and marketing analytics 


\section{BEHAVIORAL \& SOCIAL SCIENCES}

July $23-25,2021$

Stockholm, Sweden

\section{SEO Strategy}

The foundation for successful digital marketing is SEO. It refers to a number of strategies designed to boost rankings in online search results. If a website doesn't rank on the first page, most people will never find it (Emily, 2020). Search engine algorithms continue to change with time as the Web evolves, so online retailers need to evolve with the engines. The company must make sure they keep up-to-date with best practices to claim the best possible rankings for relevant keywords (Forbes, 2012). There are the components of SEO strategy

- Keywords

The definition of a keyword is a significant word, or a word used to find information when researching. Those successful with SEO understand what people are searching for when discovering their business in a search engine. These are the keywords they use to drive targeted traffic to their products. The target keywords need to meet four criteria — significant search volume, high relevance, strong conversion value, and reasonable competition.

- Content

Search engines have stated that creating quality content is the best way to not only rank for keywords, but also create positive user experiences. It will educate consumers, and being an authority in a niche will lead to boosts in the sales funnel.

- Backlinks

Backlinks (also known as "inbound links", "incoming links" or "one-way links") is a link that a website obtains from another site. Backlinks have a significant impact on the prominence of a website in search engine results. That is why they are considered very useful to improve the SEO ranking of a website. By using multiple factors search engines calculate rankings to display search results.

- Social media

Social media is a computer-based technology that facilitates the sharing of ideas, thoughts, and information through the building of virtual networks and communities. By design, social media is Internet-based and gives users quick electronic communication of content. Many content websites are communityoriented. Social media sites send search engines signals of influence and authority.

- Product images

The perceptions and attitudes of consumers towards an existing or proposed new product. Product image is affected both by the physical attributes of the product itself and by the psychological or imputed values of the buyer which can be cultivated and manipulated by ADVERTISING and other promotional forms. The quality images of products on site with the files' names contain relevant keywords, these images will rank well in search engines. This avenue will drive a lot of traffic to your site, as potential customers will click on that image to find a store. 


\title{
$8^{\text {th }}$ International Conference on Research in
}

\section{BEHAVIORAL \& SOCIAL SCIENCES}

July $23-25,2021$

\author{
Stockholm, Sweden
}

\section{SEO related vocabulary}

The following definition base on Google Analytics, the beginning and origin SEO itself and some of the metric vocabularies come from Moz, a leading company about digital marking focusing on providing SEO service and tools to help business grow.

\section{Search Query}

Search queries, on the other hand, are words or phrases that real users type into a search engine. In an essence, search queries are the real-world application of a keyword, meaning there may be other words tacked onto it, it may be misspelled, or it may just be the exact keyword itself.

\section{Domain}

A domain name defines the location of your website on the Internet. Choosing a domain for company website is an important first SEO step. Keywords in company domain are no longer an SEO ranking factor, so marketer need to choose domain name that matches your business, brand business or personality.

\section{Domain Authority}

Domain Authority (DA) is a search engine ranking score developed by Moz that predicts how likely a website is to rank on search engine result pages (SERPs). A Domain Authority score ranges from one to 100 , with higher scores corresponding to a greater ability to rank. It is calculated by evaluating multiple factors, including linking root domains and the number of total links, into a single DA score. This score can then be used when comparing websites or tracking the "ranking strength" of a website over time.

\section{Page Authority}

Page Authority (PA) is a score developed by Moz that predicts how well a specific page will rank on search engine result pages (SERP). Page Authority scores range from one to 100, with higher scores corresponding to a greater ability to rank. Page Authority uses a machine learning model to identify the algorithm that best correlates with rankings across the thousands of SERPs.

\section{Visit}

The term "visit" refers to a user who visits a website. However, a visit is not considered as a single person but as a browser or a terminal. For example, a single user can access a website via different browsers such as Google Chrome, Firefox or Microsoft Edge or different computers or different terminals. If a visitor visits a page once in the morning and once in the evening, this user is counted as a single visitor with two visits. 


\section{$8^{\text {th }}$ International Conference on Research in}

\section{BEHAVIORAL \& SOCIAL SCIENCES}

July $23-25,2021$

Stockholm, Sweden

\section{Unique visit}

The measurement of unique visitors is based on cookies. A cookie is a file placed on a browser that contains an anonymous identifier. This ID can be used to uniquely identify a browser.

As a result of this measurement method, inaccuracies may occur. For example, a browser may refuse to accept cookies, or a user may decide to delete them.

\section{Bounce rate}

A bounce is a single-page session on your site. In Analytics, a bounce is calculated specifically as a session that triggers only a single request to the Analytics server, such as when a user opens a single page on your site and then exits without triggering any other requests to the Analytics server during that session. These single-page sessions have a session duration of 0 seconds since there are no subsequent hits after the first one that would let Analytics calculate the length of the session.

\section{Traffic}

The visitors come to your website. They are grouped into different segments, depending on how they found you by channel. The commonly see used in online analytics:

- Direct traffic

Direct access (direct traffic) to a website occurs when a visitor arrives directly on a website, without having clicked on a link on another site or URL type-ins, bookmarks, or media links that are not tracked

- Campaign traffic

Campaign traffic (paid traffic) from search engines arrives to websites when a user clicks on an advertisement placed on a SERP for a given search term. This ad is created and paid for by a company with the aid of an ad platform seeking to appear first in search engines.

- Search traffic

It is a standard segment in Google Analytics that includes traffic from organic sources and the paid search to analyze traffic flows from a variety of perspectives. In general, the term search traffic refers to the number of all accesses that have been made via search engines.

- Referral traffic

Referral traffic is the segment of traffic that arrives on your website through another source, like through a link on another domain.

- Organic traffic

All traffic that comes to website as a result of unpaid search results.

\section{Reference Domain}

It also known as a ref domain; a referring domain is a domain that backlinks are coming from. Backlink: A backlink is a link on another website that points to your site 


\section{BEHAVIORAL \& SOCIAL SCIENCES}

July $23-25,2021$

Stockholm, Sweden

\section{Display Advertising}

A method of attracting the audience of a website, social media platform or other digital mediums to take a specific action. These are often made up of text-based, image or video advertisements that encourage the user to click-through to a landing page and take action (e.g. make a purchase). Most display and online advertising campaigns are charged on a cost per click (CPC) basis.

\section{Digital strategy in the life insurance industry}

According to Kotler et al. (2017), Digital strategy as a concept highlights a set of profile processes that embrace all the digital channels available to promote a product or service, or to build a digital brand. All digital tools allow marketers to find new markets and learn customer behavior for only a small investment. The organization can increase the number of customer touchpoints by enhancing the traditional protection products with broader financial suggestions and physical well-being. Digitization can deliver significant value in terms of customer satisfaction, cost-efficiency, and data utilization along with the entire life insurance business system as the following figure ("Harnessing the Power of Digital in Life Insurance", 2016).

\begin{tabular}{|c|c|c|c|c|c|}
\hline $\begin{array}{l}\text { New product } \\
\text { development }\end{array}$ & $\begin{array}{l}\text { Initial } \\
\text { consideration }\end{array}$ & $\begin{array}{l}\text { Active } \\
\text { evaluation }\end{array}$ & Purchase & Use & $\begin{array}{l}\text { Ongoing } \\
\text { engagement }\end{array}$ \\
\hline $\begin{array}{l}\text { Develop new } \\
\text { digital products } \\
\text { or business units } \\
\text { that target new } \\
\text { segments or } \\
\text { channels }\end{array}$ & $\begin{array}{l}\text { Next-generation } \\
\text { digital marketing } \\
\text { to develop } \\
\text { high-quality } \\
\text { prospects } \\
\rightarrow \text { potential } \\
3-5 \% \text { increase in } \\
\text { new sales }\end{array}$ & $\begin{array}{l}\text { Transform the } \\
\text { digital shopping } \\
\text { experience } \\
\text { Digitally enable } \\
\text { the "advisor of } \\
\text { the future" } \\
\rightarrow \text { potential } \\
3-7 \% \\
\text { improvement in } \\
\text { sales force } \\
\text { productivity } \\
\text { Transform pricing } \\
\text { through } \\
\text { advanced } \\
\text { analytics } \\
\text { Create } \\
\text { "on-demand" } \\
\text { personalized } \\
\text { products }\end{array}$ & $\begin{array}{l}\text { Digitize } \\
\text { end-to-end } \\
\text { customer } \\
\text { onboarding } \\
\text { processes } \\
\rightarrow \text { potential } \\
20-30 \% \text { FTE cost } \\
\text { reduction } \\
\text { Create a } \\
\text { frictionless } \\
\text { underwriting } \\
\text { process } \\
\rightarrow \text { potential } \\
30-40 \% \text { FTE } \\
\text { cost reduction } \\
\text { Develop } \\
\text { seamless } \\
\text { enrollment } \\
\text { process through } \\
\text { robust } \\
\text { institutional } \\
\text { partner } \\
\text { connectivity }\end{array}$ & $\begin{array}{l}\text { Digitize } \\
\text { end-to-end } \\
\text { claims } \\
\rightarrow \text { potential } \\
15-20 \% \text { FTE cost } \\
\text { reduction } \\
\text { Build omnichan- } \\
\text { nel servicing } \\
\text { capability } \\
\rightarrow \text { potential } \\
15-25 \% \text { FTE cost } \\
\text { reduction } \\
\text { Accelerate } \\
\text { data-driven } \\
\text { claims } \\
\text { management } \\
\rightarrow \text { potential 1-3 } \\
\text { points } \\
\text { improvement in } \\
\text { judgment-based } \\
\text { claims accuracy }\end{array}$ & $\begin{array}{l}\text { Build "next-best } \\
\text { product to buy" } \\
\text { cross-sell } \\
\text { capability } \\
\rightarrow \text { potential } \\
15-25 \% \text { increase } \\
\text { in cross-sell } \\
\text { rates } \\
\text { Build predictive } \\
\text { analytics } \\
\text { capability for } \\
\text { lapse reduction } \\
\rightarrow \text { potential } \\
20-30 \% \\
\text { reduction in } \\
\text { lapse rates for } \\
\text { "at risk" } \\
\text { customers } \\
\text { (accounting for } \\
\sim 70 \% \text { of total } \\
\text { lapses) }\end{array}$ \\
\hline
\end{tabular}

Figure 2.1 Digital opportunities across the business system (Mckinsey \& Company, 2016)

\section{Digital customer journey}

A customer journey is an entire experience while a customer has been communicated with a brand. It considers the complete interaction roadmap from brand discovery to purchasing and 


\section{$8^{\text {th }}$ International Conference on Research in}

\section{BEHAVIORAL \& SOCIAL SCIENCES}

July $23-25,2021$

Stockholm, Sweden

beyond. From Mckinsey research, more than $80 \%$ of shoppers now touch a digital channel at least once in their customer journey. Digital tools are unlocking new opportunities for businesses including insurers. Many commercial insurances utilize online interfaces as selfservice features and ability to track the status of interactions in real time instead of having to make inquiries by phone, email or through their brokers ("The Growth Engine", 2016). This following picture showing the general digital customer journey

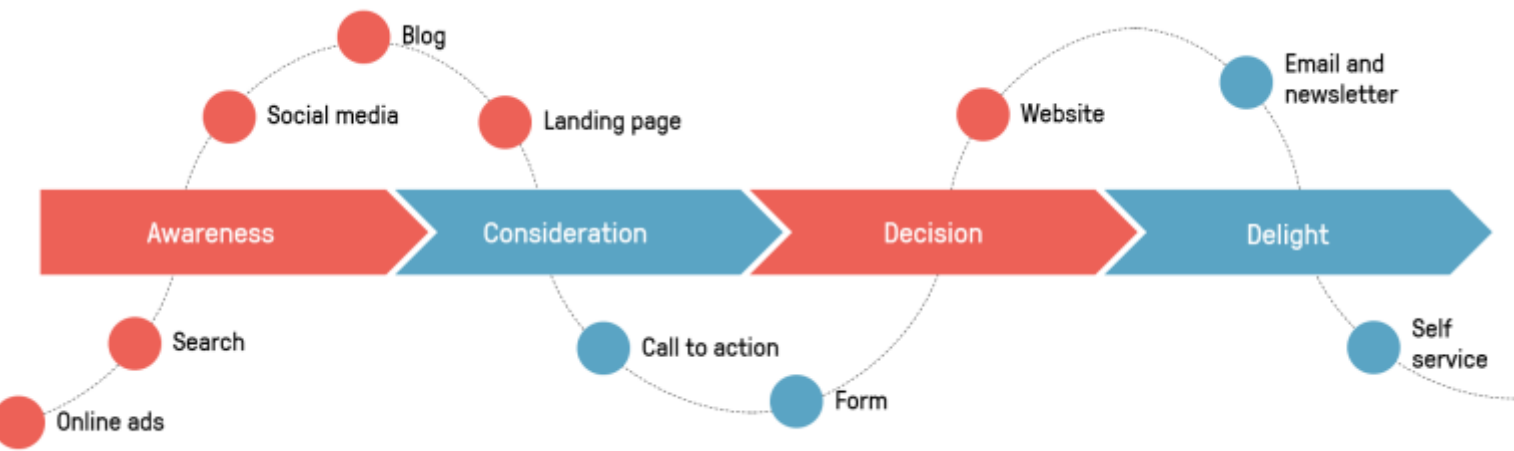

Figure 2.2 Improve your digital experiences with a better customer journey

(Siw Grinaker, 2019)

\section{Insurance Industry}

According to Dr. W.A. Dinsdale Insurance is a device for the transfer of risks of individual entities to an insurer, who agrees, for a consideration, to assume to a specified extent loss suffered by the insured. Insurance is a co-operative form of distributing a certain risk over a group of persons who are exposed to it (Ghosh and Agarwal, 2012). In the word of Prof. D.S. Hansell, "Insurance providing financial compensation for the effects of misfortune, the payments being made from the accumulated contributions of all parties participating in the scheme"

\section{Bancassurance}

An arrangement between a bank and an insurance company allowing the insurance company to sell its products to the bank's client base. This partnership arrangement can be profitable for both companies. In other word bancassurance means selling insurance product through banks. Banks and insurance company come up in a partnership wherein the bank sells the tied insurance company's insurance products to its clients."

\section{Insurance Lapse}

The policy for which all benefits to the policy holder cease and is terminated due to nonpayment of premium amount on the due date or even after the grace period is called a lapsed policy. Description: Excessive delay in payments and servicing of the policy leads to the policy being dead or lapsed. 


\section{$8^{\text {th }}$ International Conference on Research in}

\section{BEHAVIORAL \& SOCIAL SCIENCES}

July $23-25,2021$

Stockholm, Sweden

\subsection{Conceptual framework}

\section{Key performance indicator of digital marketing activity}

Normally the efficiency of the insurer is determined by the DEA model (Figure 2.3). Since then, many studies evaluating the efficiency of the commercial insurance companies around the world. At First, it was published by Charnes, Cooper and Rhodes (1978).

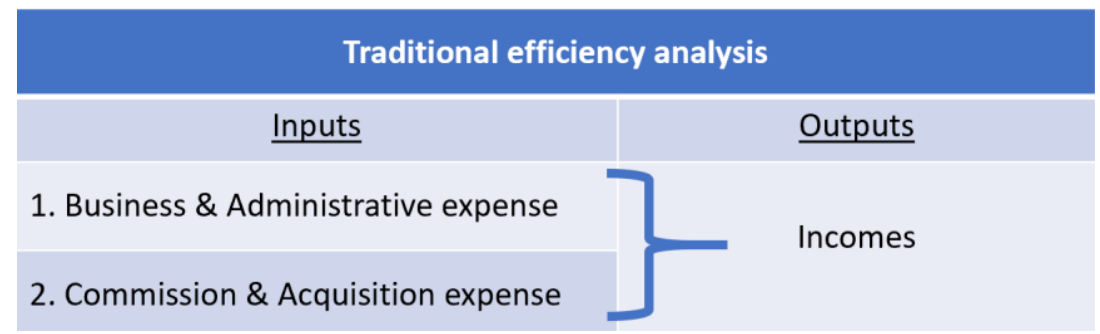

This study will focus on business expenses in terms of marketing perspective. The key performance indicators are the marketing efficiency, return on investment, return on asset etc.

\section{Return on marketing investment}

ROMI is a metric used to measure the overall efficiency of a marketing campaign. ROMI is usually used in online marketing, this ratio helps marketers improve budget allocation strategy in the future investments though integrated campaigns: social media, search engine, marketing media and advertising may also rely on for determining overall success. In financial terms ROMI is a subset of ROI (return on investment) ("ROMI", 2008). Seobi et al. (2014) applied ROMI measured return of marketing investments in the life insurance companies in South Africa. They found that ROMI measurement allowed marketers to account for marketing activities and drive sales both short term and long term. In each case, Mank et al. (2019) from the Boston consulting group reported that developing cross-functional marketing KPIs can drive value for the broader business (such as by increasing customer value versus driving additional click-throughs). The complex companies applied marketing ROI as a corporate objective. They integrated marketing indicators to broader business objectives and compiled marketing into business decisions. The ROMI ratio can simply by formula (Figure 2.4)

$\begin{gathered}\text { Return on Marketing } \\ \text { Investment (ROMI) }\end{gathered}=\frac{\text { Incremental Revenue }}{\text { Marketing Cost }}$

Figure 2.4 ROI Calculator for Marketing (Prorelevant, 2017)

The data from www.marketingevolution.com refer that "The rule of thumb for marketing ROI is typically a 5:1 ratio, with exceptional ROI being considered at around a 10:1 ratio. Anything below a 2:1 ratio is considered not profitable, as the costs to produce and distribute goods/services often mean organizations will break even with their spend and returns" 


\section{BEHAVIORAL \& SOCIAL SCIENCES}

July $23-25,2021$

Stockholm, Sweden

\subsection{Research hypothesis}

1. The digital marketing strategy increases competitiveness.

2. Digital marketing strategy affected sales; companies that run strategy success will receive additional market share.

\section{Chapter 3. Methodology}

\subsection{Research designs}

This research is aimed to evaluate the insurance service in the time of digitalization and faces scenarios of implementation in the marketing strategy online component (Prymostka, 2018). The study has adopted a qualitative method of data gathering and analysis particularly for its suitability to understand and uncover a complex phenomenon (Ghauri \& Gronhaug, 2002: 88). Mainly explorative in nature, this study uses the netnographic method to assess and explore the digital marketing strategy and online brand communications to expand the knowledge of the unstudied phenomenon. Netnography is a qualitative, ethnographic approach specially designed to study computer-mediated communications and social interactions within online communities (Kozinets, 2010: 60). The current research chooses to focus on the company website of leading insurers. The aim is to compare digital marketing strategy and develop understanding of the nature of brand main communication platform. The focus of the analysis was explicitly on the website design and component that might influence the audience experiences and perceptions. Of particular interest were the search engines optimization that lead to the sustainable ranking on search engines, instead of the commercial messages provided by the company alone.

\subsection{Research tools}

Comparison table

Program for SEO analytic

- SEMRUSH

- MOZ Local Listing Score

- Google Analytics

Financial performance analytic

- Company's financial report

- Company investor relation information

- Office of Insurance Commission (OIC)

\subsection{Data collection}

For the online strategy towards the various aspects of digital marketing to understand the audience's experience towards the digital platform and define impact of digital strategy on the buying life insurance product in Thailand, 8 aspects of digital marketing have been administered in this study. These are -

1. Life insurance program as the name shown on the company's website

2. Customer service program as the name shown on the company's website

3. Comparison component of life insurers website as of January, 2021 


\section{$8^{\text {th }}$ International Conference on Research in}

\section{BEHAVIORAL \& SOCIAL SCIENCES}

July $23-25,2021$

Stockholm, Sweden

4. Comparison function on life insurance website as of January, 2021

5. Life insurers harness the power of digital in business system

6. Comparison of life insurer website searching result as of Jan, 2021

7. Comparison of number of keywords using on life insurer website as of Jan, 2021

8. Comparison of life insurer website traffic as of Jan, 2021

9. Effect of brand reputation to traffic on website result as of Jan, 2021

10. Comparison source of traffic of life insurer website result as of Jan, 2021

11. Comparison of company owned social media subscriber as of Jan, 2021

12. Expense on sale of life insurance companies in Thailand, million baths

13. Insurance premium of life insurance companies in Thailand, million baths

14. Market position of life insurance company in Thailand as of December 31, 2020

15. Indicators of the economic efficiency of the marketing activities of life insurance company in Thailand as of December 31, 2020

\subsection{Data Analysis}

To clarify the overview of the life insurance market in Thailand and define capability of leading players to analysis in the further part. These are 3 aspects this thesis will follow

1. Contraction of life insurance market in Thailand

2. Market share of life insurance companies in Thailand

3. Sale channel of life insurance between 2017-2019

Table1. Contraction of life insurance market in Thailand as of Dec 31, 2019

\begin{tabular}{|l|c|c|}
\hline \multicolumn{1}{|c|}{$\begin{array}{c}\text { Number of companies } \\
\text { (Top) }\end{array}$} & $\begin{array}{c}\text { Receive insurance premium, million } \\
\text { THB }\end{array}$ & Market share\% \\
\hline Top 3 & 316847 & $51.87 \%$ \\
\hline Top 5 & 420715 & $68.87 \%$ \\
\hline Top 10 & 560131 & $91.69 \%$ \\
\hline Total & 610896 & $100.00 \%$ \\
\hline
\end{tabular}

Data from Office of Insurance Commission Thailand (OIC) in 2019, there are 23 life insurance companies in Thailand. From the table1, the companies that dominance market are big 3 insurers that received more than $50 \%$ of the market share. The top 5 insurers that present on this research get about $68.87 \%$ of the market. While top 10 insurers, half of the total insurance companies in Thailand have market share more than $90 \%$, so this table show leading insurers have almost control the market. 


\section{BEHAVIORAL \& SOCIAL SCIENCES}

July $23-25,2021$

Stockholm, Sweden

Table2. Market share of life insurance companies in Thailand, million baths

\begin{tabular}{|l|c|c|c|c|c|c|}
\hline Year & AIA & TLI & FWD & SCB Life & MTL & KTAL \\
\hline 2017 & $21.03 \%$ & $13.75 \%$ & $3.87 \%$ & $8.25 \%$ & $17.10 \%$ & $7.33 \%$ \\
\hline 2018 & $21.38 \%$ & $13.75 \%$ & $4.47 \%$ & $8.11 \%$ & $15.06 \%$ & $10.68 \%$ \\
\hline 2019 & $23.07 \%$ & $15.07 \%$ & $5.84 \%$ & $7.35 \%$ & $13.72 \%$ & $9.65 \%$ \\
\hline 2020 & $23.30 \%$ & $15.21 \%$ & $13.39 \%$ & n/a & $12.55 \%$ & $9.11 \%$ \\
\hline Ranking in 2020 & 1 & 2 & 3 & n/a & 4 & 5 \\
\hline
\end{tabular}

In this research will focus on 5 insurers that dominate insurance market. There are AIA, TLI, FWD, MTL, and KTAL respectively. The first market leader is AIA, it received highest market share. From the table [2] during 2017 to 2020 AIA market share slightly increase, which in 2020 AIA market share was $23.30 \%$. AIA considered as the first multinational life insurance company go to market in Thailand. It has been in operation since 1938 with over 83 years of experience and get large customer base. Second is Thai Life Insurance company (TLI) received market share $15.21 \%$ in 2020. It is the first insurance company build and operated by Thai people during world war II. The third company is FWD insurance, its market share increases continuously in 2019 it received 5.84\% and decided to acquired SCB Life, leading Thai insurance into their portfolio making the total market share of $13.39 \%$ in 2020. Forth company is Muang Thai Life Assurance (MTL). In 2017 there is leader in the second place however it has lost market share to younger competitors until the year 2020 the expected market share is about 12.55\%. Last is Krungthai-AXA Life insurance (KTAL), co-investment partnership between Krungthai bank and the AXA group. KTAL market share during pass 4 year is steady in 2020 the expected market share is $9.11 \%$. From the table [2], it can be indicated that the major insurers have minimal change on market share reflect the ability to maintain their competitive position.

Table3. Sale channel of life insurance between 2017-2019

\begin{tabular}{|c|c|c|c|c|}
\hline Year & Agency & Bancassurance & Direct marketing & Others \\
\hline 2017 & $49.20 \%$ & $44.90 \%$ & $2.45 \%$ & $3.45 \%$ \\
\hline 2018 & $48.70 \%$ & $44.70 \%$ & $2.28 \%$ & $4.32 \%$ \\
\hline 2019 & $51.66 \%$ & $41.01 \%$ & $2.44 \%$ & $4.89 \%$ \\
\hline
\end{tabular}

From the table [3] there are four main insurance sales channels: agency, bancassurance or banking, direct selling and other channel for example broker website and company website. The two main channels agency and bancassurance cover more than $90 \%$ of total sales. Data show selling insurance through sales representative tend to increase on the other hand bancassurance channel tent to decline. For direct sales referring to tele sales still remain the sales volume at $2.44 \%$ in 2019, so this channel still practical as usual. Moreover, sales on other channel which are broker and the company own website cover only $4.89 \%$ in 2019 which raise significantly during pass 3 year. From the data, it can be seen that consumer behavior has shifted to buying insurance directly from insurer and buying insurance through the website has also grown in popularity. 


\section{BEHAVIORAL \& SOCIAL SCIENCES}

July $23-25,2021$

Stockholm, Sweden

\section{Chapter 4. Results}

Harnessing digital power in business system

Table1. Life insurance program as the name shown on the company's website

\begin{tabular}{|c|c|c|c|c|c|}
\hline Product & AIA & TLI & FWD & MTL & KTAL \\
\hline Life & $\begin{array}{l}\text { - Life insurance } \\
\text { - Legacy } \\
\text { Prestige } \\
\text { - Term insurance }\end{array}$ & $\begin{array}{l}\text { - Life insurance } \\
\text { - Life insurance } \\
\text { for elder } \\
\text { - Micro } \\
\text { insurance }\end{array}$ & $\begin{array}{l}\text { - Life } \\
\text { protection } \\
\text { - Legacy }\end{array}$ & $\begin{array}{l}\text { - Life } \\
\text { protection }\end{array}$ & $\begin{array}{l}\text { - Life } \\
\text { insurance }\end{array}$ \\
\hline Health & $\begin{array}{l}\text { - Medical } \\
\text { insurance } \\
\text { - Critical illness } \\
\text { protection }\end{array}$ & $\begin{array}{l}\text { - Medical } \\
\text { insurance } \\
\text { - Critical illness } \\
\text { protection }\end{array}$ & $\begin{array}{l}\text { - Health } \\
\text { protection }\end{array}$ & $\begin{array}{l}\text { - Health } \\
\text { protection } \\
\text { - Critical } \\
\text { illness }\end{array}$ & $\begin{array}{l}\text { - Health } \\
\text { insurance and } \\
\text { Hospital } \\
\text { income }\end{array}$ \\
\hline Accident & $\begin{array}{l}\text { - Accident } \\
\text { protection } \\
\text { - Disability } \\
\text { protection }\end{array}$ & $\begin{array}{l}\text { - Accident } \\
\text { protection } \\
\text { - Disability } \\
\text { protection } \\
\text { - Accident } \\
\text { protection for } \\
\text { disabled person }\end{array}$ & $\begin{array}{l}\text { - Accident } \\
\text { protection } \\
\text { - Disability } \\
\text { protection }\end{array}$ & $\begin{array}{l}\text { - Personal } \\
\text { accident }\end{array}$ & $\begin{array}{l}\text { - Accident } \\
\text { and Critical } \\
\text { insurance }\end{array}$ \\
\hline Saving & - Saving & - Saving & - Saving & $\begin{array}{l}\text { - Saving } \\
\text { - Takaful }\end{array}$ & - Saving \\
\hline Pension & - Retirement & - Retirement & - Retirement & - Retirement & - Retirement \\
\hline $\begin{array}{l}\text { Group } \\
\text { insurance }\end{array}$ & $\begin{array}{l}\text { - Employee } \\
\text { benefit } \\
\text { - AIA reginal } \\
\text { solution }\end{array}$ & $\begin{array}{l}\text { - Employee } \\
\text { benefit }\end{array}$ & $\begin{array}{l}\text { - Employee } \\
\text { benefit }\end{array}$ & $\begin{array}{l}\text { - Employee } \\
\text { benefit }\end{array}$ & $\begin{array}{l}\text { - Health } \\
\text { package }\end{array}$ \\
\hline $\begin{array}{l}\text { Other } \\
\text { product }\end{array}$ & $\begin{array}{l}\text { - Unit linked } \\
\text { - AIA Vitality } \\
\text { protection } \\
\end{array}$ & $\begin{array}{l}\text { - Unit linked } \\
\text { - Life Fit }\end{array}$ & & - Unit linked & - Unit linked \\
\hline
\end{tabular}

The product information from the website of each company show that the basic of life insurance products of every company are indifference. However, the market leader company differentiate themselves form the other by develop new products and services. AIA and FWD launched the Legacy product aimed to target high net worth customer who generate significant sales for the company. The new product development is Unit linked, insurance alongside investment product, mutual fund. Product design aims to provide more flexible payment methods and provide opportunity to generate better returns in the long run. The companies applied Unit linked product in their portfolio are AIA, TLI, MTL and KTAL. For the products that develop align with health-conscious trend are Vitality protection issued by AIA and Life Fit products issued by TLI. These products will give discount every year if the customer does 


\section{BEHAVIORAL \& SOCIAL SCIENCES}

July $23-25,2021$

Stockholm, Sweden

good health behavior for example exercise, answer health questionnaire or do yearly health checkup, etc.

Table2. Customer service program as the name shown on the company's website

\begin{tabular}{|c|l|l|l|l|l|}
\hline Product & \multicolumn{1}{|c|}{ AIA } & \multicolumn{1}{c|}{ TLI } & FWD & \multicolumn{1}{c|}{ MTL } & KTAL \\
\hline $\begin{array}{c}\text { Customer } \\
\text { service }\end{array}$ & $\begin{array}{l}\text { - Medix } \\
\text { - AIA Prestige } \\
\text { club }\end{array}$ & $\begin{array}{l}\text { - MSO (medical } \\
\text { second opinion) } \\
\text { - Privilege club }\end{array}$ & N/A & $\begin{array}{l}\text { - mit Global } \\
\text { Doctors } \\
\text { - mti smileclub }\end{array}$ & - Telehealth \\
\hline
\end{tabular}

Not only quality product but also, they are services to delight customer. To respond health-conscious trend, AIA launched Medix, a global and leading provider of innovative, high quality, medical case management from diagnosis through recovery. Medix' team is comprised of in-house doctors alongside nurses, medical admin, research teams and a quality accredited global network. This program Exclusively for AIA Vitality members and health lump sum insurance customers. Next programs are MSO (Medical Second Opinion) of TLI and Telehealth of KTAL these services provides an independent review of your diagnosis and treatment plan by top medical minds in world leading medical centers without travelling out of the country. All of the service will optimize customer treatment plan and improve health outcomes. Last important item are privilege clubs, all of the long history insurers in Thailand: AIA LIT and MTL have their own club loyal customer. These club not only maintain the customer retention rate but also delight customer that built reputation to the company. From the table [4] and table [5], it reflects that leader insurers have products and services more comprehensive than others.

Table3. Comparison component of life insurers website as of January, 2021

\begin{tabular}{|c|c|c|c|c|c|}
\hline Criteria & AIA & TLI & FWD & MTL & KTAL \\
\hline Corporate website & $\begin{array}{c}\text { www.aia.co.th } \\
\text { www.aia.com/en }\end{array}$ & www.thailife.com & www.fwd.co.th & www.muangthai.co.th & $\begin{array}{l}\text { www.krungthai- } \\
\text { axa.co.th }\end{array}$ \\
\hline Language selection & $\begin{array}{l}\text { Thai, English but } \\
\text { in separately page }\end{array}$ & Thai, English & English & Thai, English & Thai, English \\
\hline $\begin{array}{l}\text { Out standing } \\
\text { visual content }\end{array}$ & $\begin{array}{c}\text { Image pack, } \\
\text { location pack, } \\
\text { Knowledge panel, } \\
\text { site link }\end{array}$ & $\begin{array}{c}\text { image pack, site } \\
\text { link }\end{array}$ & $\begin{array}{c}\text { knowledge } \\
\text { panel, site link }\end{array}$ & $\begin{array}{c}\text { Image pack, site link, } \\
\text { top story }\end{array}$ & $\begin{array}{c}\text { image pack, site } \\
\text { link }\end{array}$ \\
\hline $\begin{array}{l}\text { Information about } \\
\text { the company }\end{array}$ & Yes & Yes & Yes & Yes & Yes \\
\hline $\begin{array}{l}\text { Client's personal } \\
\text { profile }\end{array}$ & No & No & Yes & Yes & No \\
\hline $\begin{array}{l}\text { Separate feedback } \\
\text { form }\end{array}$ & No & No & No & Yes & No \\
\hline Chat bot & Yes & No & Yes & Yes & No \\
\hline $\begin{array}{l}\text { Website link to } \\
\text { social network }\end{array}$ & $\begin{array}{l}\text { FB, Youtube, } \\
\text { Line, Instagram }\end{array}$ & $\begin{array}{l}\text { FB, Youtube, } \\
\text { Line, Instagram }\end{array}$ & $\begin{array}{l}\text { FB, Youtube, } \\
\text { Line, Instagram }\end{array}$ & $\begin{array}{l}\text { FB, Youtube, Line, } \\
\text { Instagram, Twitter, } \\
\text { LinkedIn }\end{array}$ & $\begin{array}{c}\text { FB, Youtube, } \\
\text { Line, Instagram, } \\
\text { Twitter, LinkedIn }\end{array}$ \\
\hline
\end{tabular}




\section{BEHAVIORAL \& SOCIAL SCIENCES}

July $23-25,2021$

Stockholm, Sweden

To understand how corporate communication works in online based on the fact that companies' websites are a major component of present-day corporate communication. Within companies' websites insurers are dedicated to disclosing the message-sender's institutional profile [Breeze, 2013; Esrock \& Leichty, 2000; Perry \& Bodkin, 2002; Pollach, 2005; Turnbull, 2011, 2013]. Insurers provide information about an organization while presenting its positive image as a reliable business partner. The basic website component, tactics that insurer use to connect with audience or customer will included in table [3].

In the language sections, International insurers like AIA and FWD have an English language website as their main site. AIA has a separate Thai website specifically to penetrate Thai market and increase communication effectiveness. However, FWD not apply on this therefore, online searching result may not reach some customers who are not use English in everyday life. While Thai insurers website have both Thai and English accordance the language spoken by the majority.

For the visual content all company applied Image pack and Site link. Using Image pack to deliver the message as it enhances the understanding. The Site link or Link building is the popular tactic use by insurers. This process is getting other websites into link back or forward to company website, it drives referral traffic which benefit SEO score by increase company site's authority. Take a deep look in AIA site, the outstanding tactic constituted Location pack, Knowledge panel. The local pack is a SERP feature that effect to any search query with a local intent the results appears on the first page. This features map business locations along with listings for top relevant to a particular search. In mean to help when combine with the Knowledge panel the information boxes that appear on Google when audience search for entities. Audience will get a quick snapshot of information on a topic; hence it helps AIA reach local people better than other insurers that have it but few. The outstanding tactic of MTL is call Top story. This feature give positive effect to SEO by generally appear current news composed of what Google deems the most relevant article which gives an opportunity to have more people entering the system es as the result of search query.

Every insurer has information about the company part on their site. However, in term of personalize audience experience not all company concern that. Only FWD and MTL has feature client's personal profile which help audience better understand the insurance product and might select one that proper for them. Not only the personalize part but those company also have chatbot therefore customer more comfortable to find contact point. Moreover, only MTL has separate feedback form which may show the audience that company care about customer experience and ready for changing to be better. Accordingly, in term of website design MTL consider as the best player which be an opportunity to analyze and qualify lead entering the system. Besides the information on the website, insurers also create some link building to connect audience with their social media. Most of the company will link all popular social media on the site. All of the attempt will be analyzed and evaluated in the next part 


\section{$8^{\text {th }}$ International Conference on Research in}

\section{BEHAVIORAL \& SOCIAL SCIENCES}

July $23-25,2021$

Stockholm, Sweden

Table4. Comparison function on life insurance website as of January, 2021

\begin{tabular}{|l|c|c|c|c|c|}
\hline \multicolumn{1}{|c|}{ Criteria } & AIA & TLI & FWD & MTL & KTAL \\
\hline $\begin{array}{l}\text { Pay insurance } \\
\text { premiums online }\end{array}$ & Yes & Yes & Yes & Yes & Yes \\
\hline $\begin{array}{l}\text { Online order policy } \\
\text { application form) }\end{array}$ & No & No & Yes & Yes & No \\
\hline $\begin{array}{l}\text { Delivery of an } \\
\text { insurance contract, } \\
\text { issued online }\end{array}$ & No & No & Yes & Yes & No \\
\hline $\begin{array}{l}\text { The opportunity to } \\
\text { report an accident } \\
\text { online }\end{array}$ & No & No & Yes & Yes & No \\
\hline Mobile app & Yes, & $\begin{array}{c}\text { Yes, Thai } \\
\text { life insurance }\end{array}$ & $\begin{array}{c}\text { Yes, FWD } \\
\text { MAX }\end{array}$ & Yes, mtl click & $\begin{array}{c}\text { MyAXA } \\
\text { Life }\end{array}$ \\
\hline
\end{tabular}

The functions on the website play important role to differentiate and make competitiveness. Nowadays financial payment is more advance and reliable so every insurer allow customer to pay insurance premium online via website, application or mobile banking. On the other hand, only few companies applied online application form. From many research and statistics said Thai people still comfort with the traditional sales channel. Insurance sale agent and bancassurance are still be the most popular channels. Thus, insurance life products are tailor made, they have a lot of detail. Customer expect sale agent to take care of them on the after the finish buying process such as payment period and claim process. The companies let customer buy insurance policy online without contact with any sale person, there are FWD and MTL. Use online order policy as well as delivery of an insurance contract to the customer residence. Moreover, customer of these two insurers can report the accident online. Although in the present these services are not completely applying with all of the claim that might occur but these provide convenient and confident to the customer and decrease employee workload. The global trend reflects that online policy are the important key in nearly future since customer in digital era spend more time online and access to information by themselves. Brand that can increase digital awareness along with provide one stop service with digital channel will have advantage. 


\section{$8^{\text {th }}$ International Conference on Research in}

\section{BEHAVIORAL \& SOCIAL SCIENCES}

July $23-25,2021$

Stockholm, Sweden

Table5. Life insurers harness the power of digital in business system

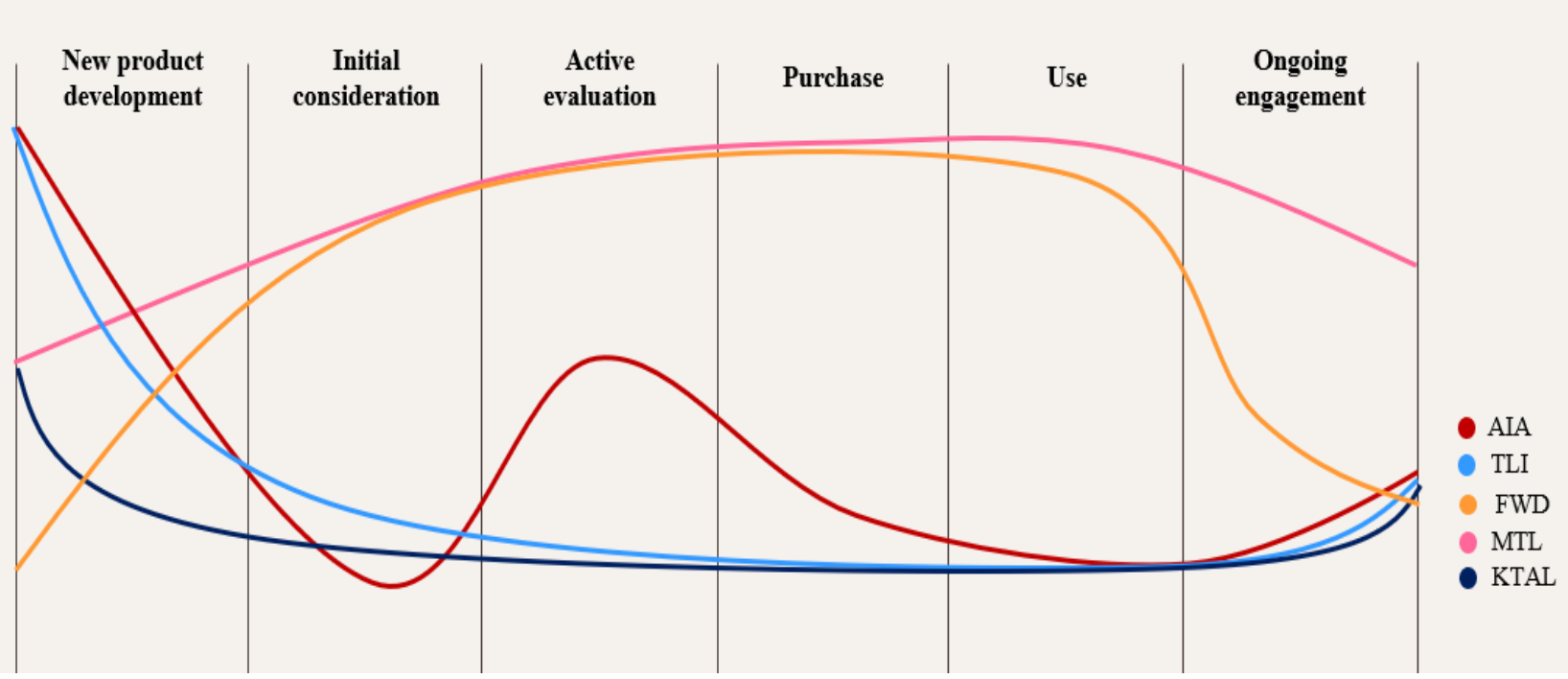

Form the data from table [1] to table [4] can infer how leading insurers have made use of digital to improve their processes. It can be seen that many companies have not done all the processes. New product development topic, the outstanding companies are AIA and TLI have variety of products and service, examining the investment and health trend. These products help insurer to penetrate new customer segment also be able to partner with companies to create new sales channels as well, while other companies have developed applications.

For the outstanding company use digital marketing to develop high qualities prospects that might increase new sales are FWD and MTL. In these two companies' website visitors can create profile and choose the products that best suit them. The information giving the company a rough overview of its customers and their needs provide a better chance of sales than any other company. Other company haven't been done in this section. In term of transform pricing and create on-demand personalize products many leading companies can do well at this point via the product call Unit linked. The unit linked innovation not only provide adjusted insurance and investment plan but also reduce insurance policy lapse rate which normally accounting for $70 \%$.

The online self-purchasing and using online claims of insurance policies nowadays is not very common in Thailand. Only FWD and MTL develop features on the website. For other companies' customers still need to contact an insurance agent or call center if the claim process cannot be automated in the medical center.

Finally, in terms of cross selling, at present, because the main sales channel is still agent, so it focuses on selling with relationships rather than utilizing digital. Some companies, such as AIA, TLI, MTL, and KTAL application interfaces, have summarized the protections that customers have. This may be a trigger makes people who are already customers understand what areas they have and lack in coverage which might increase chance to do cross sale. In terms of policy lapses, as mentioned above, from the insurers statistic the unit link product can 


\section{BEHAVIORAL \& SOCIAL SCIENCES}

July $23-25,2021$

Stockholm, Sweden

actually help reduce lapse rates. Therefore, this is the positive sign that the life insurance industry in Thailand is adapting to the digital age.

\section{SEO analysis}

Table6. Comparison of life insurer website searching result as of Jan, 2021

\begin{tabular}{|l|l|l|l|l|l|}
\hline SEO Criteria & AIA & TLI & FWD & MTL & KTAL \\
\hline $\begin{array}{l}\text { Site order in Google searching "life } \\
\text { insurance" }\end{array}$ & 2 & 1 & 11 & 3 & 4 \\
\hline Domain Authority & 34 & 41 & 35 & 41 & 40 \\
\hline Page Authority (a page on the top search) & 20 & 25 & 36 & 25 & 25 \\
\hline
\end{tabular}

The SEO marketing literature was one of the first area in which digital marketing research began. In digital world search engines optimization specialists and PPC advertisers work together to maximize audience visibility. More than $90 \%$ of traffic goes to websites that rank on the first page of Google search engines results page (SERP), since users are more likely to click on results at the top of the page. In table [6], searching query "life insurance" on Google on January 2021 show the following result: first second third and froth place are TLI, AIA, MTL and KTAL respectively. FWD ranked as eleventh on the searching result which quite low nevertheless FWD recently revamped their strategy become leading insurer from acquire SCB Life last year, 2018. Accordingly, FWD website were adjusted recently so it takes time to build higher ranking for the domain. Since Google ranking algorithm in present are very complex. The high-quality website will help to ranked higher. To measure the quality of website, there are 2 key performance indicators Page authority and Domain authority. They're initiated by MOZ, the leading SEO tools represent the score of the site.

Page authority ranks the content within a website while Domain authority is a score of the website's overall authority. For the domain, the first two companies scored highest of 41 are TLI and MTL. Followed by another Thai company KTAL domain authority scored of 40. Next is FWD scored of 35 and AIA scored of 34 respectively. It can be seen that even if the company rank the first of market share but overall website authority score is not able to complete with its competitors. Another KPI show on the table [6] is page authority score of each company's first page on the SERP. The first company received highest scored at 36 of FWD. Followed by three Thai companies with the same score of 25 which are TLI, MTL and KTAL. Last but not lease is AIA page authority scored of 20. Both of KPI show that AIA digital strategy is not focus on website quality score as its competitors. The reason is AIA already well-known and be a top of mind so their website rank on the top of search result automatically. During FWD, the newcomer is more devoted to website than any other company for building their reputation. 


\section{$8^{\text {th }}$ International Conference on Research in}

\section{BEHAVIORAL \& SOCIAL SCIENCES}

July $23-25,2021$

Stockholm, Sweden

Table7. Comparison of number of keywords using on life insurer website as of Jan, 2021

\begin{tabular}{|l|c|c|c|c|c|}
\hline \multicolumn{1}{|c|}{ SEO Criteria } & AIA & TLI & FWD & MTL & KTAL \\
\hline Number of total keywords on Domain & $7.6 \mathrm{k}$ & $5 \mathrm{~K}$ & $2.3 \mathrm{~K}$ & $5.8 \mathrm{~K}$ & $3.6 \mathrm{~K}$ \\
\hline Number of total keywords on SERP & $1.1 \mathrm{k}$ & 166 & 211 & 424 & 229 \\
\hline Keyword on the top rank & 110 & 4 & 35 & 37 & 32 \\
\hline
\end{tabular}

\section{Number of total keywords on Domain}

Keyword overlap

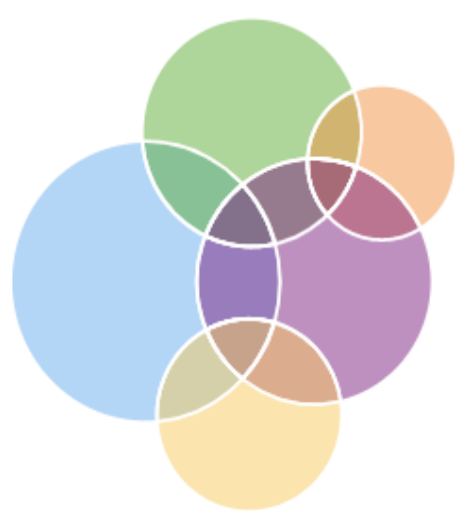

$\begin{array}{lr}\square \text { aia.co.th } & 7.6 \mathrm{~K} \\ \square \text { thailife.com } & 5 \mathrm{~K} \\ \square \text { Fwd.co.th } & 2.3 \mathrm{~K} \\ \square \text { muangthai.co.th } & 5.8 \mathrm{~K} \\ \square \text { krungthai-axa.co.th } & 3.6 \mathrm{~K}\end{array}$

\section{Number of total keywords on SERP}

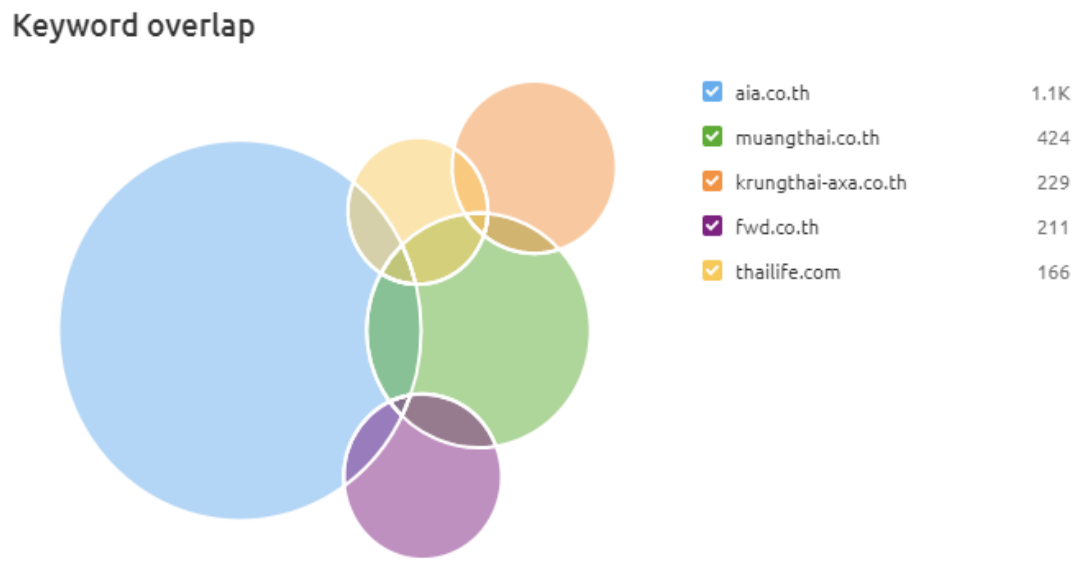

In any search engines optimization initiative, implementing keyword are first important steps. Keyword is words or phrases that describe what company content is about. It determines which particular content is relevant search query, and how the page should rank in searches. Therefor keyword help company site rank above their competitors. In table [7] show the number of total keywords and identify number of keywords that each insurer develops to be ranked on the top. When considering the domain, it is found that the number of keywords used by each company is different. The largest number of keywords are AIA, MTL, TLI, KTAL and 


\title{
BEHAVIORAL \& SOCIAL SCIENCES
}

July $23-25,2021$

\author{
Stockholm, Sweden
}

FWD respectively. However, if considering the overlapping keywords Leading companies such as AIA, TLI, MTL and KTAL have overlapping keywords. While FWD have less keywords that are overlapped especially it hasn't overlap keywords with AIA the market leader company. This part is seen as a strategy of FWD tries to differentiate itself in search to create its own space since having more keywords than your competitors doesn't always mean more success.

Considering at number of total keywords using on search engines result page the result show that AIA implements it the most at 1,100 keywords following by MTL, KTAL, FWD and TLI respectively. In term of successful keyword on the other hand call "keyword on the top rank" the insurer who can develop the most is AIA. Keyword on the top rank help company win on search marketing campaign so AIA who can develop about 110 keywords to the top rank has competitive advantage than other. Next insurers have top rank keywords are MTL, FWD, KTAL and TLI respectively. One of the areas that AIA and MTL have achieved in top rank keyword is their implement total keyword than other companies also they use more keywords that match the search that target audience use than any other company.

Table8. Comparison of life insurer website traffic as of Jan, 2021

\begin{tabular}{|l|l|l|l|l|l|}
\hline SEO Criteria & AIA & TLI & FWD & MTL & KTAL \\
\hline Visit & $1.6 \mathrm{~m}$ & $402 \mathrm{k}$ & $235 \mathrm{k}$ & $564 \mathrm{k}$ & $142 \mathrm{k}$ \\
\hline Unique visit & $594 \mathrm{k}$ & $160 \mathrm{k}$ & $120 \mathrm{k}$ & $235 \mathrm{k}$ & $119 \mathrm{k}$ \\
\hline Avg. visit duration (min) & 9.28 & 10.24 & 8.3 & 12.01 & 6.16 \\
\hline Pages per visit & 5.19 & 3.91 & 2.71 & 3.52 & 2.11 \\
\hline Bounce rate & $32.72 \%$ & $44.58 \%$ & $55.16 \%$ & $39.52 \%$ & $61.50 \%$ \\
\hline
\end{tabular}

After analyzing the overview of the website, then take a look at the behavior of audience that visit each company website. For approximately in January 2021 AIA has the most website traffic of 1.6 million, followed by traffic of MTL, TLI, FWD and KTAL respectively. To add more accuracy, another metric that has been used is the unique visit. It collects the visitor value from the cookies of people who use the web service, which likely to estimate the number of real people. Found that AIA has real visitor on their website about 549 thousand people. Followed by the visitor number of MTL about 235 thousand people, TLI about 160 thousand people, FWD and KTAL come closely about 120 thousand and 119 thousand people. According to all the visitor data, it was found that the estimated number of people who actually viewed each website was 2-3 times less than the total traffic. The traffic of FWD more than and close to KTAL. Consider in conjunction with the ranking on SERP in the table [6], found that FWD, although at lower rank 11, can generate traffic as well as the website ranked 4. Therefore, considered the result of number of visits on website FWD is impressive.

Next step is to start analyzing the audience behavior they have visited on the website with the following indicator. First the average visit duration(min) on the website. It shows how much content can trigger the customer's interest. A longer period of time is a positive sign. It means audience is interested in the company and can get useful information. The result show MTL does it the best follow by TLT, AIA, FWD and KTAL respectively. Second indicator is 


\section{BEHAVIORAL \& SOCIAL SCIENCES}

July $23-25,2021$

Stockholm, Sweden

page per visit. Nowhere can figure out how many pages per visit would be best, having not too much or too little pages is a good idea. For too many, may mean customers can find information difficult and have to decide multiple times, while few may mean customers are unenjoyed. AIA has the most follow by TLT, MTL, FWD and KTAL respectively. Last indicator is bounce rate, the percentage of visitors who bounce off of company site. By default, Google Analytics considers a visitor to have interacted with your site if they visited at least one additional page. Less bounce rate is good. A bounce rate of $56 \%$ to $70 \%$ is on the high side while $41 \%$ to $55 \%$ would be considered an average bounce rate. An optimal bounce rate would be in the $26 \%$ to $40 \%$ range. AIA and MTL are in the optimal zone. TLT and FWD are on the average while KTAL website received high bounce rate of $61.50 \%$. From the table [8], it can be concluded the overall audience experience on website. MTL is better than AIA follow by TLT, FWD and KTAL respectively.

Table9. Effect of brand reputation to traffic on website result as of Jan, 2021

\begin{tabular}{|l|l|l|l|l|l|}
\hline Source of traffic & AIA & TLI & FWD & MTL & KTAL \\
\hline Brand traffic & $18.10 \%$ & $56.83 \%$ & $38.51 \%$ & $8.42 \%$ & $38.77 \%$ \\
\hline Non brand traffic & $81.90 \%$ & $43.17 \%$ & $61.49 \%$ & $91.58 \%$ & $61.23 \%$ \\
\hline
\end{tabular}

In table [9] and table [10], they focus on source of traffic. The division of traffic source can be categorized in several ways, in Table [9] the factor take into account is the brand reputation. The brand that utilize the most of their reputation to the online website traffic is TLI, first Thai insurer. More than haft of TLI traffic come from searching involve brand name, brand product or any element that involve with the brand. Therefore, it can be seen that TLI is the top of mind in term of brand search. Next insurer can utilize brand reputation to traffic are KTAL, FWD, AIA and MTL respectively. The traffic that rely on brand is good but if the company is unable to make it stand out then other strategies should be added. When considering together with data from table [8], it can be seen that AIA and MTL do very well. Not only rely on brand only but also utilize other SEO tools which show in the table [10].

Table10. Comparison source of traffic of life insurer website result as of Jan, 2021

\begin{tabular}{|l|l|l|l|l|l|}
\hline Source of traffic & AIA & TLI & FWD & MTL & KTAL \\
\hline Organic search traffic & $342.9 \mathrm{k}$ & $24.4 \mathrm{k}$ & $32.2 \mathrm{k}$ & $78.7 \mathrm{k}$ & $18.2 \mathrm{k}$ \\
Organic partner: Reference domain & $1.1 \mathrm{k}$ & 902 & 950 & 483 & 626 \\
\hline Paid search traffic & 13 & 50 & 876 & $1.3 \mathrm{k}$ & 1 \\
Paid partner: Display advertising & 43 & 29 & 94 & 470 & 92 \\
\hline Backlinks & $856.4 \mathrm{k}$ & $784.9 \mathrm{k}$ & $823.3 \mathrm{k}$ & $1.1 \mathrm{~m}$ & $2.9 \mathrm{~m}$ \\
\hline
\end{tabular}

Each insurer has different online marketing strategy. In table [10] mention about overall of strategy effect to traffic on website. This part will analyze traffic source base on the organic/paid search which popular and widely used. In roughly way some people will consider as traffic from SEO and SEM marketing. In present even using search engines marketing (SEM) or paid method to acquire lead is expensive and not sustainable. However, for newbie 


\section{BEHAVIORAL \& SOCIAL SCIENCES}

July $23-25,2021$

Stockholm, Sweden

or company in highly competition SEM is one of the most used tactics. In order to analyze one by one follow by market share.

The first company is AIA, as it shown strong traffic come from organic search. One of the key success factors is AIA has the most reference domain compares with competitors. It means AIA has 1.1 thousand media partner that more than its competitors. Having more partner send positive impact to AIA's backlinks. Since backlinks of AIA come from viral source that mean the content may reach out to many groups of audience than other. On the other hand, AIA not focus on the paid advertising that much, as it shown only 43 display advertising applied. As few display advertisings applied their paid search traffic is only 13 leads.

TLI online marketing focus on SEO marketing as well as AIA. The main reason is TLI, leading insurer in Thailand already well known so building content, develop service by using SEO are long term sustain strategy. However, when considering the number of online content partner both organic and paid, reference domain of 902 and display advertising of 29. TLI has online media partner quite lower than competitors. It one of most the reasons that, TLI although very well-known but might not effective to acquire audiences as it should be.

Next is FWD. Although FWD is newbie compare with other leading insurers, FWD has traffic at a satisfactory level. FWD has 950 reference domains, which is second only to AIA and FWD can accumulate a lot of backlink if consider with the time. Although not a lot, FWD applied 876 display advertising that lead to 94 traffics per month. It has more numbers than the two leading companies previously mentioned, so it can be said that FWD is mainly focus on organic search engines.

Let's continue at MTL, although MTL has the 4th market share, the traffic comes in the 2nd place. Its backlink that mean the number of contents refer to the company ranks second after KTAL. Although it has a small number of reference domain, the number of backlinks from content writing is quite high at 1.1 million. It can assume that MTL focus on some partner, using financial to launch content frequently. Considering together with paid method display advertising. MTL has more than all competitors with 470 display ads. It leads to 1.3 thousand traffics per month so it could be said that MTL online marketing is efficiency. It focuses both on organic and paid marketing.

Last but not lease is KTAL, this insurer has the 5th market share and has the lowest organic traffic among top 5 competitors. When considering the amount of backlink as extremely high as 2.9 million. The presence of reference domain at moderate level. It is understood that large number of backlinks is not effective. Considering paid marketing 92 display advertising is more than its competitors, AIA and TLI. However only 1 paid traffic per month in return. Overall, it can be considered that KTAL does online marketing a lot but not efficiency as it should be.

In this research, we focus on the SEO strategy that takes place on the website. However, in the world of online marketing, not only the website is important, but also the social media that people in that country use. Social medias are important channel each company interacts with their customers and builds a brand image. In Table [11] would analyze each brand's social 


\section{BEHAVIORAL \& SOCIAL SCIENCES}

July $23-25,2021$

Stockholm, Sweden

media followers to demonstrate that each brand online marketing strategy focus in any particular channel.

\section{Company's social media}

Table11. Comparison of company owned social media subscriber as of Jan

\begin{tabular}{|l|c|c|c|c|c|}
\hline \multicolumn{1}{|c|}{ Social media } & AIA & TLI & FWD & MTL & KTAL \\
\hline Facebook & $658 \mathrm{~K}$ & $600 \mathrm{~K}$ & $1.2 \mathrm{M}$ & $994 \mathrm{~K}$ & $374 \mathrm{~K}$ \\
\hline Instagram & $16.6 \mathrm{~K}$ & $3.4 \mathrm{~K}$ & $7.5 \mathrm{~K}$ & $1.3 \mathrm{~K}$ & $4.1 \mathrm{~K}$ \\
\hline YouTube & $49.9 \mathrm{~K}$ & $252 \mathrm{~K}$ & $21.4 \mathrm{~K}$ & $39.2 \mathrm{~K}$ & $10.3 \mathrm{~K}$ \\
\hline Twitter & N/A & $8 \mathrm{~K}$ & $8.1 \mathrm{~K}$ & $1.66 \mathrm{~K}$ & 578 \\
\hline LinkedIn & $8.4 \mathrm{~K}$ & $6.3 \mathrm{~K}$ & $\begin{array}{c}\text { N/A } \\
\text { nave specific for } \\
\text { Thailand }\end{array}$ & $5.4 \mathrm{~K}$ & $4.8 \mathrm{~K}$ \\
\hline $\begin{array}{l}\text { Search result on } \\
\text { Pantip.com }\end{array}$ & 264,000 & 314,000 & 75,100 & 241,000 & 87,700 \\
\hline
\end{tabular}

In this research, we focus on the SEO strategy that takes place on the website. However, in the world of online marketing, not only the website is important, but also the social media that people in that country use. Social medias are important channel each company interacts with their customers and builds a brand image. In Table [11] would analyze each brand's social media followers to demonstrate insurers online marketing strategy focus in any particular channel.

Starting with the Facebook channel, the most popular social media cover $69.7 \%$ of Thai people. It can be seen that the first company has the number of followers about 1.2 million is FWD. The number of followers followed by MTL, AIA, TLI and KTAL respectively. A high number of FWD's followers may come from the aggressive marketing. As FWD is the newest among these 5 brands, the company need to raise brand awareness as possible. MTL also has high follower compared with the peer. Since their market share has been a continuous decline in the past 3 years, causing the company to do aggressive marketing as well.

Instagram channel is the platform that focuses primarily on brand image rather than sales. The data show that AIA is the 1st number of followers, followed by FWD, KTAL, TLI and MTL respectively. It can be seen that the first 3 brands with the highest Instagram followers are foreign brands or brands that cooperate with foreign insurance businesses. The analysis found that the customer base on Instagram is mostly Gen Y or below. Beyond that, it makes the image of foreign brands look more accessible meet the needs of users of the platform.

On YouTube, which is a channel that presents stories through videos or provide lengthy advertisements uploaded on the platform. It was found that the 1st insurer with the highest number of followers is TLI followed by AIA, MTL, FWD and KTAL respectively. At this point, it can be seen that TLI has exceptionally high follower numbers. Due to the brand's reputation that has created advertising films that have touched the hearts of Thai people for a 


\section{$8^{\text {th }}$ International Conference on Research in}

\section{BEHAVIORAL \& SOCIAL SCIENCES}

July $23-25,2021$

Stockholm, Sweden

long time. There is the brand identity eventually. Where other company use this channel for promote their product and service as well but not outstanding as TLI.

In Thailand, the Twitter channel is useable in some the topic, such as related to breaking news, entertainment and politics. However, in terms of business, it is not yet clear how well it works. In the table [11] can be notice that some company does not have its own Twitter account. The brand with the highest followers in Twitter account is FWD followed by TLI at quite similar follower, then it is MTL and KTAL respectively. It can assume that FWD intends to continually penetrate the Thai market by doing aggressive marketing on this channel as always. While TLI also has a fairly large number of followers by taking advantage of word-of-mouth commercials. The rest of Thai companies started play on this platform as well.

LinkedIn is the platform for professional, in term of marketing it promotes company reliability. AIA has a separate account of Thailand particular with the most followers compared to its competitors at 8.4 thousand people. The following insurer's follower in LinkedIn are TLI, MTL and KTAL respectively. FWB currently hasn't LinkedIn account specifically for Thailand. From the analysis it can be understood that LinkedIn channel is not for create brand awareness to the public or do sale and marketing, but rather for recruiting professional to work with.

Lastly, Pantip.com Thai's social Media which is a good channel to do social listening. The information in the table show the number of topics that people have conversation about each brand. Some company may hire content writer to create marketing content to the brand as well. Therefore, the number of topics can be assumed how brands are motivate interest to people. The first leader is TLI, followed by AIA, MTL, KTAL and FWD respectively.

Considering at many channels together, it can be concluded that AIA all aspects of its social media accounts are high standards. TLI where widely well-known in Thai peoples making leverage from memorable advertising movies to boost brand reputation. FWD, the brand that is considered the newest among the top five computers does aggressive marketing in popular social media. MTL focuses mainly marketing on Facebook's channel until it is superior to competitors while other social media are on the average. Last but not lease is KTAL, this company seems to be focus on Instagram but for other social media channels are not stand out in particular. 


\section{BEHAVIORAL \& SOCIAL SCIENCES}

July $23-25,2021$

Stockholm, Sweden

Financial performance

Table12. Sale and marketing expenditure of life insurance companies in Thailand, million baths

\begin{tabular}{|c|c|c|c|c|c|c|}
\hline Year & Expense & AIA & TLI & FWD & MTL & KTAL \\
\hline \multirow{4}{*}{2020} & $\begin{array}{l}\text { Agency fee and } \\
\text { commission from } \\
\text { insurer }\end{array}$ & $\begin{array}{c}15,221 \\
(37.3 \%)\end{array}$ & $\begin{array}{c}12,235 \\
(58.8 \%)\end{array}$ & $\begin{array}{c}4,166 \\
(44.1 \%)\end{array}$ & $\begin{array}{c}9,123 \\
(61.8 \%)\end{array}$ & $\begin{array}{c}8,262 \\
(64.2 \%)\end{array}$ \\
\hline & Marketing expenditure & $\begin{array}{c}16,562 \\
(40.6 \%)\end{array}$ & $\begin{array}{c}2,151 \\
(10.3 \%)\end{array}$ & $\begin{array}{l}419.02 \\
(4.4 \%)\end{array}$ & $\begin{array}{c}760 \\
(5.2 \%)\end{array}$ & $\begin{array}{c}680 \\
(5.3 \%)\end{array}$ \\
\hline & $\begin{array}{l}\text { Promotional expense } \\
\text { Advertisement } \\
\text { expense }\end{array}$ & $\begin{array}{c}16,378 \\
183\end{array}$ & 1,599 & 154.07 & 200 & 421 \\
\hline & Operation expense & $\begin{array}{l}40,828 \\
(100 \%)\end{array}$ & $\begin{array}{c}20,820 \\
(100 \%)\end{array}$ & $\begin{array}{c}9,442 \\
(100 \%)\end{array}$ & $\begin{array}{c}14,760 \\
(100 \%)\end{array}$ & $\begin{array}{c}12,871 \\
(100 \%)\end{array}$ \\
\hline
\end{tabular}

Ref: $\quad$ The Thai Life Assurance Association, annual report 2020

In table [13] analyze data from company income statement to review sale \& marketing budget spending comparison to the total operation cost as $100 \%$ The two major marketing items are "Agency fee and commission" and "Marketing expenditure". Analyzing these two items to review overall marketing strategy of each company. The first item, Agency fee and commission from insurer, refers to how much the company is interested in supporting sale agents and commissioning their employees. The second item, Marketing expenditure, refers to the financial booster that the company uses for marketing, which is divided into 2 sub-items: Promotional expense and Advertisement expense.

For companies that have the highest proportion of using money with sale agent management and commission fees are KTAL, MTL, TLI, FWD and AIA respectively. When evaluating the actual expenses incurred together, it was found that AIA and TLI spent more than 10,000 million baht per year on this item. Taking into account that today, more than half of the insurance sales in Thailand are made through insurance agents. Making it understandable that for KTAL and MTL invests a lot in this part to increase the number of sales agents as much as the two leading companies mentioned above. FWD can be seen that it not spends much budget in this section as competitors due to two main reasons. First, there hasn't acquired many insurance agents as other companies. Another reasons, the current main sales channel is bancassurance since it acquired SCB Life last year that backing up with the SCB, Thailand second place commercial bank.

The next item Marketing expenditure, overall AIA has spent the significant proportion in this segment. It clearly more than $40.6 \%$ of the AIA's operation expense. The most percentage spending on marketing expenditure segment followed by TLI, KTAL, MTL and FWD respectively. Focusing on each sub item, AIA spends 16,378 million baht per year on promotional expense, which is several times more than its competitors while advertisement expense less than all. Considering in 2020 AIA sale and marketing strategy focus on sale promotion and after sale service rather than advertising. TLI spent on both promotional and advertising expense ranked $2^{\text {nd }}$ among its competitors, consider TLI focused on both sides. FWD doesn't spent money in promotion that much, but focuses on advertising to make more widely awareness. MTL spent on promotion budget not that much but devoted to advertising 


\section{BEHAVIORAL \& SOCIAL SCIENCES}

July $23-25,2021$

Stockholm, Sweden

section which be the most among all competitors. The main reasons were the fact that the market share declined continuously and the company name in Thai language of Muang Thai Life Assurance similar to Thai Life Assurance, causing the company to accelerate their branding. Last KTAL since the company has devoted its budget to insurance agents and commission fee, the existing marketing budget is in the middle level. Considering advertising expense, it is less than many competitors.

Since each company has devoted its budget to boost sales in different ways depending on its strategy. The most notably AIA allocated a lot of their budget to promotions part to response higher competition. Another outstanding is KTAL has spent a lot of money on its sales agent since the main channel for selling insurance products in Thailand is insure representative. However, in term of result as first year premium it seems like.

Table13. Insurance premium of life insurance companies in Thailand, million baths

\begin{tabular}{|l|c|c|c|c|c|c|}
\hline Year & AIA & TLI & FWD & $\begin{array}{c}\text { SCB } \\
\text { Life }\end{array}$ & MTL & KTAL \\
\hline 2017 & 126,259 & 82,527 & 23,222 & 49,514 & 102,681 & 44,005 \\
\hline 2018 & 134,412 & 86,268 & 28,049 & 50,911 & 94,467 & 67,036 \\
\hline 2019 & 140,952 & 92,055 & 32,356 & 44,925 & 83,840 & 58,943 \\
\hline 2020 & 145,850 & 91,291 & 80,368 & n/a & 75,326 & 54,679 \\
\hline $\begin{array}{l}\text { CAGR } \\
\text { CAGrs }\end{array}$ & $3.7 \%$ & $3.7 \%$ & $11.7 \%$ & $-3.2 \%$ & $-6.5 \%$ & $10.2 \%$ \\
\hline
\end{tabular}

Ref: $\quad$ The Thai Life Assurance Association, annual report 2020

Office of insurance commission Thailand website

Insurance premium of life insurance companies show in table [13]. This table reveals sales figures for the past 3 years, 2017-2019 and the number of premiums in 2020 is also included. The reason this research show sale in 2020 is the figures revealed after FWD acquired SCB Life which making it the third-place market share. The last row of table [13] show 3 years compound annual growth rate of total premium.

From the data, it can be seen that AIA and LTI CAGR have steady growth at around $3.7 \%$ percent per year, which review can their potential continue to dominate the market. While FWD's receive extreme growth rate from 2017 to 2019 around $11.7 \%$ per year. In the same period found that SCB Life growth rate has dropped to $3.2 \%$ per year. That is one reason why SCB agreed to sell the company subsidiary, SCB Life to FWD, reduce the overall business burden and be more competitive in the market. The next insurance is MTL 3 years ago had huge decline of growth rate and lost market share to competitors, CAGR at $-6.5 \%$. Last is KTAL although the growth rate is up to $10.3 \%$. However, when looking at the exact number of premium volumes are fluctuated each year.

It can be concluded that AIA and TLI have good growth rates while being wary of competitors such as FWD and KTAL which have high sales growth rates. For MTL performance has continued to decline, it is a strategy to maintain its position and survive in the digital era. 


\section{BEHAVIORAL \& SOCIAL SCIENCES}

July $23-25,2021$

Stockholm, Sweden

Table14. Market position of life insurance company in Thailand as of December 31, 2020

\begin{tabular}{|l|c|c|c|c|c|}
\hline Indicator & AIA & TLI & FWD & MTL & KTAL \\
\hline First Year & 21,719 & 15,566 & 18,877 & 9,657 & 8,231 \\
Premium & $21 \%$ & $15 \%$ & $19 \%$ & $9 \%$ & $8 \%$ \\
\hline New Business & 29,166 & 20,457 & 29,071 & 21,566 & 11,749 \\
Premium & $18 \%$ & $13 \%$ & $18 \%$ & $14 \%$ & $7 \%$ \\
\hline Renewal Year & 116,697 & 70,831 & 51,257 & 53,775 & 42,905 \\
Premium & $26 \%$ & $16 \%$ & $12 \%$ & $12 \%$ & $10 \%$ \\
\hline \multirow{2}{*}{ Total Premium } & 145,850 & 91,291 & 80,308 & 75,326 & 54,679 \\
& $24 \%$ & $15 \%$ & $13 \%$ & $13 \%$ & $9 \%$ \\
\hline
\end{tabular}

Ref: $\quad$ The Thai Life Assurance Association, annual report 2020

AIA, annual report 2020

Thai Life Insurance, annual report 2020

FWD Thailand, annual report 2020

Muang Thai Life Assurance, annual report 2020

Krungthai AXA, annual report 2020

In Table [14], It shows market position of life insurance company in 2020 by review all premium types including items: First Year Premium (FYP) is the new sales made in that year, New Business Premium is the FYP plus Single premium or one-time revenue, which means total new revenue generated in that year, Renewal Year Premium means continued revenue from existing customers, and finally, Total Premium is the total revenue for that year.

In 2020, it was found that companies with New Business Premium Ranked No. 1 are AIA FWD, MTL, TLI and KTAL. On the other hand, when considering together with First Year Premium, it can be seen that MTL more rely on Single Premium or the one-time purchase policy. Therefore, the annual customer base of MTL may be less than other companies. Considering the Renewal Year Premium, it was found that the leading company, AIA had the largest customer base, followed by TLI, MTL, FWD and KTAL respectively. Considering the total premiums, it is found that companies have the total premiums sorted by market share as previously mentioned. From all data it is clear that after FWD merger with SCB Life, the received customer base and ability to find new customers are better than MTL and have opportunity to challenge the second market share, TLI in the future. 


\section{BEHAVIORAL \& SOCIAL SCIENCES}

July $23-25,2021$

Stockholm, Sweden

Table15. Indicators of the economic efficiency of the marketing activities of life insurance company in Thailand as of December 31,2020

\begin{tabular}{|c|c|c|c|c|c|}
\hline Indicator & AIA & TLI & FWD & MTL & KTAL \\
\hline $\begin{array}{l}\text { First Year Underwriting Expenses: Net } \\
\text { First Year Premiums }\end{array}$ & $85.30 \%$ & $47.33 \%$ & $80.30 \%$ & $42.63 \%$ & $62 \%$ \\
\hline $\begin{array}{l}\text { Renewal Underwriting Expenses: Net } \\
\text { Renewal Premiums }\end{array}$ & $13.60 \%$ & $11.45 \%$ & $18.70 \%$ & $9.47 \%$ & $10 \%$ \\
\hline Return on Equity Ratio & $5.10 \%$ & $10.21 \%$ & $-6 \%$ & $11.29 \%$ & $3 \%$ \\
\hline $\begin{array}{l}\text { Return on Asset Ratio } \\
\text { Return on Total Assets Ratio }\end{array}$ & $1.30 \%$ & $1.58 \%$ & $-0.2 \%$ & $1.45 \%$ & $0.50 \%$ \\
\hline $\begin{array}{l}\text { Return on Asset Ratio excluding Unit } \\
\text { linked and Universal life }\end{array}$ & $1.20 \%$ & $1.58 \%$ & $-0.2 \%$ & $1.44 \%$ & $0.50 \%$ \\
\hline $\begin{array}{l}\text { Return on Investment Ratio } \\
\text { Return on Investment Ratio }\end{array}$ & $3.10 \%$ & $3.44 \%$ & $2.60 \%$ & $3.62 \%$ & $3.02 \%$ \\
\hline $\begin{array}{l}\text { Return on Investment Ratio excluding } \\
\text { Unit } \\
\text { linked and Universal life }\end{array}$ & $3.20 \%$ & $3.31 \%$ & $2.80 \%$ & $3.65 \%$ & $3.12 \%$ \\
\hline Return on Marketing Investment & 1.8 & 9.5 & 69.4 & 28.4 & 17.3 \\
\hline $\begin{array}{l}\text { Invested Asset: Policy Reserve (Admitted } \\
\text { Value) }\end{array}$ & $160.80 \%$ & $123.22 \%$ & $109.70 \%$ & $118.39 \%$ & $113 \%$ \\
\hline
\end{tabular}

Ref: AIA, annual report 2020

Thai Life Insurance, annual report 2020

FWD Thailand, annual report 2020

Muang Thai Life Assurance, annual report 2020

Krungthai AXA, annual report 2020

Indicators of the economic efficiency of the life insurance company is determined by Thai Life Assurance Association and Office of insurance commission. The first 2 ratios represent expenses to premium received, which a small percentage better than a large percentage comes out. Found that MTL was the least achievable in terms of both First Year First Year Underwriting and Renewable Underwriting. Whereas the company that lost the most money on acquiring new customer was AIA and the company that lost the most money on secure existing customer was FWD.

Return on Equity, the company with the highest ROE is MTL, followed by TLI, which are the leading Thai company. For the reason ROE of AIA and KTAL less than Thai company because both companies are international company enters to do business in Thailand or joint venture with Thai companies. They use debt as a financial cost more than other companies. While FWD's ROE is negative due to large borrowings to acquire SCB Life in the past year. As for the Return on Assets, the company with the highest ROA is at TLI, followed by MTL, AIA, KTAL and FWD respectively. Excluding Unit Linked and Universal Life products, which are exclusively investment products. The ratio is not much different.

For the overall Return on Investment, it was found that the company with the highest ROI was MTL followed by TLI, AIA, KTAL and FWD, respectively. The exclude Unit Link and Universal Life ROI ratios was not significantly different. Next is the Return on Marketing 


\section{BEHAVIORAL \& SOCIAL SCIENCES}

July $23-25,2021$

Stockholm, Sweden

Investment. Normally it should be around 5 to 10 , high ratio is better nevertheless it up to the industry as well. Thailand life insurance industry average ROMI is 6.3. If which company get ROMI higher than the average mean they are better marketing efficiency. It was found that the most effective marketing company in 2020 is FWD at extremely high score 69.4. The reason was 2020 financial report included sale of SCB Life thus increasing sales through consolidation rather than general normally. The companies with high ROMI followed by MTL, KTAL, TLI and AIA respectively. Although in many aspects of the measurement factor AIA is always at the top, but when considering the cost-effectiveness of marketing expenditure, the results returned, AIA ROMI is only 1.8. The analyze is AIA overpaid on marketing budget compare with its competitors and not getting results as it should be.

Last item is the Invested Asset or the reserve by Bank of Thailand policy. Trusted companies are able to invest more proportion of their money than other companies. This index itself is reflect the creditworthiness of a company. The company can invest the most is AIA followed by TLI, MTL, KTAL and FWD respectively. This sorting is sorted in order of company experience and market share. In the future, FWD will have a chance to invest in a larger proportion than today.

\section{Chapter 5. Conclusion and discussion 5.1 Conclusion}

The aim of this paper was to study digital marketing application and efficiency of leading life insurance company in Thailand to recommendation for other companies that want to complete the markets. Numerous data have been studied and analyze by reliable digital tools and market expert's resource. The results show that the use of internet in various marketing activities that related to clients affects traffic to the company's assets. Combining with development product, online feature and more distribution channel the company create audience's positive mindset towards services. These can delight audience who may turn to customer and improve company position in term of market share. The study done by Hosseini et al. (2008) indicated that there is a positive and significant relationship between online marketing and financial performance. Nowadays the way of communicating with customers has changed. Customers can find information on their own and prepare better. Therefore, the company combines effective communication along with marketers are increasingly using websites and social media to communicate in order to gain a competitive advantage in the market.

In this paper, it was firstly assumed that the digital marketing strategy increases competitiveness and effect sales. From a survey of the top 5 companies' websites, search engine result page and number of social medias followers. It was found that implement effective marketing compensate brand's reputation advantage. As FWD, the newcomer has the best digital marketing result measured by ROMI, which comes from getting high premiums receive even spent less marketing budget compare with the peers. The marketing strategy of the organization focuses on building brand recognition by target group of keywords differential from market leaders and dedicate in Facebook channel which is social media Thai people use the most. Some organization has changed significantly due to catalyst, sale decrease continuously as MTL. Nowadays, it has the highest quality website, the most online service 


\section{BEHAVIORAL \& SOCIAL SCIENCES}

July $23-25,2021$

Stockholm, Sweden

readiness, also can maintain return on investment at a satisfactory rate. KTAX has significant sale growth and good financial performance even their digital marketing strategy doesn't stand out in any particular area. The company focuses on sale agents and promotion. Therefore, the details are beyond the scope of the research. Next TLI, its drama short films have been the main selling point of the brand for a long time including a wide variety of products and services. However, in the long run, these selling points may not enough when considering the new sales that have taken to fourth place. Last but not lease AIA, even though every aspect of performance is great it trades with the significant number of sale and marketing budget, especially promotions budget than competitors make ROMI the last rank. I consider that AIA is dedicated to building customer base to expect income from the renewal year premium which is the long-term income of the insurance industry.

I can summarize and compare the efficiency of insurers digital marketing strategy. However, each company has a different context so different marketing strategies been applied. The impact on sales of digital marketing is inconclusive as there are many dimensions involved in sales. One of the key factors is there haven't specific information of sale through online channels of each company.

\subsection{Discussion}

In this paper, existing knowledge on efficiency of digital marketing strategy is reviewed in the context of company's digital asset including website, social medias and application. Unlike in other industry, insurance as a consequence the digital transformation remains a low priority. I propose a DEA model to evaluate the overall performance and ROMI to specifically define the contribution to profit attributable to marketing. The findings of this paper have several implications.

All the products and services listed on the insurance company's websites are discussed. The products that make a difference of each company are related to technology and wellbeing products. In the service sector, which focuses on serving the high net worth and loyal customers in terms of satisfaction from receiving services is not clarify because today customers are mainly dealing thought insurance agent. Therefore, although the service is digital to analyze the customer journey and experience of each impression cannot be concluded whether it is from the service design or whether insurance agent performance individually.

As for the features on the leading companies' websites, some of them have begun to evolve to fit the current trend, such as being able to buy policies online, home delivery services, and online claim. All of the process allows customer skip using life insurance agents, if the services are fully function it will create positive impact. Cost reduction to the company and reduce human error and service time are expected. This kind of development signals is positive to the insurance industry in Thailand. Since countries with highly competitive of insurance industry as America, Canada and Japan have been developed seriously and has succeeded in many parts. In Table [5], it can be seen that leading insurers in Thailand have not yet harness digital power in all aspect of the integrated processes. Leading companies mainly focus on new product development and there are still a room of development for more services 


\section{BEHAVIORAL \& SOCIAL SCIENCES}

July $23-25,2021$

Stockholm, Sweden

As for SEO analysis part, it is found that the results of the analysis like the digital marketing hypothesis nowadays. The organic marketing is more effective and sustainable in the long run than any paid marketing. Whereas new brands or if company want to promote their reputation in short term, it is still necessary to use paid marketing. Applied media partner and using keywords are fundamental. More number of keywords applied are better. From the analysis, to be more focus on the success factor it was found that the most important thing is develop top search engine ranking for a targeted keyword phrase which generally give company site a higher conversion rate.

In the financial performance section, I analyzed income statement focusing on agency fee and commission from insurer and marketing related expenditure in proportion to operation expense. As well as analyzed each company's sales growth and results of important ratio form by Office of Insurance Commission and the Thai Life Assurance Associate. It was found that the newest leading company has a very high return on marketing investment and has a significant level of growth. While the company that sales have dropped continuously, in the year of the analysis it has developed an online marketing strategy that outstanding from the competitor and has a highly return on marketing investment. Whereas some leading companies that success in many aspects received low return on marketing because of the over investment while the outcome less compared to competitors. This may be seen as a long-term development budget. Competitive position in the market affects the digital strategy of the insurance company. Even in the present, direct online sales reach a small proportion. But raising awareness and building customer demand through online communication is likely to increase with significant impact in the future. Therefore, it can be concluded that leading companies in Thailand value the development of marketing strategies in order to maximize results and maintain competitiveness.

\subsection{Implication for business}

According to the findings of this research, to effectively implement digital marketing strategy engage today's consumer, insurers should:

- Development the personalize insurance products related to health conscious and financial well-being holistically with beyond just life insurance. Since few companies have succeeded these trends. According to the result there not only help business to target new customer segments but also generate positive buzz and reduce insurance lapse rate.

- As the trend of online shopping in particular has increased. When consider all elements on the company online asset it is the great possibility of online order policy effect on life insurance and investments product. It is recommended that insurance companies allocate some section of their website to product customization and give customer choices to compare and learn it by their own.

- Based on the online support has been used more in general. It can create competitive advantage among the components. It is recommended to insurance companies make digital self-service channels more readily available and easy to use. Provide amenities online service, most updated facilities combine with 


\section{BEHAVIORAL \& SOCIAL SCIENCES}

July $23-25,2021$

Stockholm, Sweden

some recommendation from professional agent to increase their market share and be informed from the latest changes in processes, services, and products in the fastest possible time.

- To improve customer satisfaction and build a community interested in similar matters. Companies should bring offline marketing events that already hold every year communicate on online channel for example company application. When customers feel involved with the company, they can create long-term benefits, especially in the insurance industry.

- Keyword selection is a fundamental aspect of digital marketing. The results of market leaders reveal that a certain number of keywords are mutually reused and effective keywords. Therefore, it recommends that any company looking to develop keywords should apply that word group and add some word group that are related to the highlight of the company and can different to themselves from competitors.

- According to the variety of social media channels make it more accessible to customers. It is recommended that insurance companies should exist in all social media channels. In addition, the point of intimate communication with customers often comes from insurance agents' account. Therefore, companies should be prepared communication pack and support for agents to work more conveniently.

\subsection{Research recommendation}

Here, some subjects are recommended as follows to researchers who may intend to investigate in fields related to the topic of this paper:

- The impact of digital marketing applications on insurance companies increased profits

- To study the impact of using digital distribution channels to customer satisfaction in the hospitality industry

- To study the impact of training insurance sales agent to companies increased sales

- To study the role of customer information security in digital marketing

- The impact of culture on customers' internet usage

- The impact of social media on customer decisions

- To study the obstacles customers, face when using online features and obtaining company information.

- The impact of online ordering on sales of service companies

- To study the impact of other digital marketing forms on life and insurance investment.

\subsection{Limitation and further research}

This research approaches the topic from an exploratory and contextual abstract level. Therefore, the sections are beyond the scope of this research such as detail of the differences between sale agent training, affiliate marketing or other business partner are not count. The study is also limited to only digital marketing strategies created by companies. Whereas digital 


\title{
BEHAVIORAL \& SOCIAL SCIENCES
}

July $23-25,2021$

\author{
Stockholm, Sweden
}

analytics tools have been developed to understand the importance, usability, and effectiveness perceived by algorithms which does not directly measure the actual use results. There is also a potential for some overlap of timing between databases I use. Although it can be certain, due to the I use the average number of customer behavior data. There is therefore a small chance of overlap between databases, but this should be minimal.

\section{References}

1. Harnessing the Power of Digital in Life Insurance. (2016, October). Retrieved November 15, 2020, from https://www.mckinsey.com/ /media/McKinsey/Industries/Financial\%20Services/Our $\% 20$ Insights/Harnessing\%20the\%20power\%20of\%20digital\%20in\%20life\%20insura nce/Harnessing-the-power-of-digital-in-life-insurance.pdf.

2. Kotler P. and Keller K.L., (2012), Marketing Management. Upper Saddle River, New Jersey: Pearson Prentice Hall 14th Edition, 1-50.

3. Definition of digital marketing (2015, August 22). Financial Times. Archived from the original on November 18, 2020

4. The Four Faces of Digital Marketing (n.d.). American Marketing Association. Retrieved November 18, 2020

5. Internet user penetration in Thailand from 2017 to 2025. Statista.com. Retrieved November 11, 2020. From https://www.statista.com/statistics/975067/internetpenetration-rate-in-thailand/

6. Philip Kotler, Hermawan Kartajaya \& Iwan Setiawan. Marketing 4.0. Moving from Traditional to Digital, Published by John Wiley \& Sons, Inc., Hoboken, New Jersey, 2017, p. 32

7. Economic Outlook Report 2019 (pp. 33, Rep.). (2019). Deloitte Thailand. Retrieved November 12, 2020, from

https://www2.deloitte.com/content/dam/Deloitte/th/Documents/about-deloitte/thabout-economic-outlook-1h-2019.pdf.

8. Insurance Premium Report 2020. Office of Insurance Commission. Retrieved November 20, 2020, from http://www.fpo.go.th/main/Economic-report/FinancialResults/11376-(4).aspx

9. Growth Credibility. (n.d.). Retrieved November 12, 2020, from https://www.oic.or.th/sites/default/files/file_download/ediiyw_final_khpph_hnangsuueaephnphathnaakaarprakanphay_chbabthii_3_resize_1.pdf.

10. Department, P., \& 17, J. (2020, July 17). Thailand: Internet penetration rate 20172025. Retrieved February 07, 2021, from https://www.statista.com/statistics/975067/internet-penetration-rate-in-thailand/

11. Neilson, L. (2019, February 01). The importance of an effective insurance website. Retrieved February 07, 2021, from https://www.neilsonmarketing.com/importanceeffective-insurance-website-1-

2/\#: :text=A\%20well\%2Ddesigned\%20website\%20with,know\%20that\%20you're\%2 Oactive. 


\section{BEHAVIORAL \& SOCIAL SCIENCES}

12. Kotler, P., Adam, S., Denize, S. M., \& Armstrong, G. (2009). Principles of marketing. Frenchs Forest, NSW: Pearson/Prentice Hall.

13. Bains, P. et al., (2011) Essentials of marketing, Oxford University Press

14. Desai, D. (2019, March). Fostering Innovation, Integration and Inclusion Through Interdisciplinary Practices in Management. Retrieved January 31, 2021, from https://www.researchgate.net/publication/333709419_Digital_Marketing_A_Review\# : :text=Digital\%20marketing\%20is\%20the\%20marketin,and\%20any\%20other\%20di gital\%20medium.

15. Emily, C. (2020, December 07). Digital Marketing Components: 7 Elements You Gotta Have. Retrieved December 15, 2020, from https://www.webfx.com/blog/marketing/digital-marketing-components-5-elementsof-a-successful-digital-marketing-strategy

16. Council, Y. (2015, January 26). The 6 basic components of a Strong seo strategy for online retailers. Retrieved February 07, 2021, from https://www.forbes.com/sites/theyec/2012/08/03/the-6-basic-components-of-a-strongseo-strategy-for-online-retailers/?sh=670094b4ea53

17. Harnessing the Power of Digital in Life Insurance (2016, October). Mckinsey \& Company. Retrieved November 19, 2020

18. The Growth Engine: Superior Customer Experience in Insurance (2016, March). Mckinsey \& Company. Retrieved November 25, 2020, from https://www.mckinsey.com/ /media/mckinsey/industries/financial\%20services/our\%2 0insights/the\%20growth\%20engine \%20superior\%20customer\%20experience $\% 20 \mathrm{in} \%$ 20insurance/the_growth_engine_superior_customer_experience_in_insurance_may_2 016.pdf

19. Grinaker, S. (2019, January 28). Improve your digital experiences with a better customer journey [Web log post]. Retrieved November 25, 2020, from https://enonic.com/blog/improve-your-digital-experiences-with-a-better-customerjourney

20. Tariq, S. (2018, August 4). A Study of Customer Preference on Private Life Insurance Company with special reference to Srinagar City. Retrieved May 5, 2021, from http://proceeding.conferenceworld.in/ICMR-2018/21.pdf

21. Manmohan, A. and Madanmohan, G. (2012, January 30). Insurance, definition of Insurance, characteristics of Insurance, nature of Insurance, functions of insurance. Retrieved May 07, 2021, from https://advocatedelhi.wordpress.com/insurancedefinition-of-insurance-characteristics-of-insurance-nature-of-insurance-functions-ofinsurance/

22. Hansell, D.S. (1989). Elements of insurance. In 1365128248998479085 D. Hansell (Author), Elements of insurance (pp. 7-9). London, Pitman.

23. Charnes, A., Cooper, W. W., \& Rhodes, E. (1978). Measuring the efficiency of decision-making units. European Journal of Operational Research, 2(6), 429-444.

24. What is the return on marketing investment (ROMI)? (2008, October 14). Definition from WhatIs.com. Retrieved November 25, 2020, from https://whatis.techtarget.com/definition/return-on-marketing-investment-ROMI 


\title{
BEHAVIORAL \& SOCIAL SCIENCES
}

July $23-25,2021$

\author{
Stockholm, Sweden
}

25. Lerato Precious, S. (2013). The importance of measuring return of marketing investments in the insurance industry (Master's thesis, University of Johannesburg, 2013) (pp. 66-76).

26. Mank, T., Rich, N., Bona, C., Bellefonds, N., \& Recchione, T. (2019, October 07). Marketing Measurement Done Right. Retrieved November 26, 2020, from https://www.bcg.com/publications/2019/marketing-measurement-done-right

27. ROI Calculator - How are your investments performing? (2017, April 03). Retrieved November 27, 2020, from https://prorelevant.com/roi-calculator/

28. Evolution, M. (n.d.). Marketing ROI: Definition and How to Calculate It: Marketing Evolution. Marketing ROI: Definition and How to Calculate It | Marketing Evolution. https://www.marketingevolution.com/marketing-essentials/marketing-roi.

29. Can Insurance Companies Incentivize Their Customers to Be Healthier? (2017, June 23). Harvard business review. Retrieved November 15, 2020, from https://hbr.org/2017/06/can-insurance-companies-incentivize-their-customers-to-behealthier

30. Prymostka, O. (2018, May 30). Life insurance companies marketing strategy in the digital, Retrieved February 4, 2021, from

https://www.researchgate.net/publication/328029673_Life_insurance_companies_mar keting_strategy_in the digital_world

31. Ghauri, P., \& GRONHAUG, k. (2002). business research methods in business studies a practical Guide (2nd Ed.). SYDNEY Prentice Hall. - references - scientific research publishing. (2002). Retrieved February 04, 2021, from

https://www.scirp.org/(S(i43dyn45teexjx455qlt3d2q))/reference/ReferencesPapers.as px?ReferenceID=1797144

32. Desai, D. (2019, March). Fostering Innovation, Integration and Inclusion Through Interdisciplinary Practices in Management. Retrieved January 31, 2021, from https://www.researchgate.net/publication/333709419_Digital_Marketing_A_Review\# $: \sim$ :text=Digital\%20marketing\%20is\%20the\%20marketin, and\%20any\%20other\%20di gital\%20medium.

33. Breeze, R. (2013). Corporate discourse. London: Bloomsbury

34. Esrock, S. L., \& Leichty, G. B. (2000). Organization of corporate web pages: Publics and functions. Retrieved February 27, 2021, from

https://www.sciencedirect.com/science/article/abs/pii/S0363811100000515?via\%3Di $\underline{\text { hub }}$

35. Perry, M., \& Bodkin, C. D. (2002). Fortune 500 manufacturer web sites. Innovative marketing strategies or cyberbrochures? Industrial Marketing Management, 31, 133 144 Retrieved February 27, 2021, from https://www.sciencedirect.com/science/article/abs/pii/S0019850101001870?via\%3Di $\underline{\text { hub }}$

36. Pollach, I. (2005). Corporate self-presentation on the WWW. Strategies for enhancing usability, credibility and utility. Corporate Communications: An International Journal, 10(4), 285-301 Retrieved February 27, 2021, from https://www.emerald.com/insight/content/doi/10.1108/13563280510630098/full/html 


\section{$8^{\text {th }}$ International Conference on Research in}

\section{BEHAVIORAL \& SOCIAL SCIENCES}

July $23-25,2021$

Stockholm, Sweden

37. Turnbull, J. (2011). How 'glocal' is corporate discourse? A case study of a multinational's website. In R. Salvi, \& H. Tanaka (Eds.), Intercultural interactions in business and management (pp. 73-90). Bern: Peter Lang.

38. Turnbull, J. (2013). Tracking the evolution of genres: The case of corporate websites. In F. Poppi, \& W. Cheng (Eds.), The three waves of globalization: Winds of change in professional, institutional and academic genres (pp. 37-55). Cambridge: Cambridge Scholars Publishing.

39. Hosseini, Seyed Ahmad; Ghazizadeh, Mostafa; Abbasi E., Hussein, (2008), "Assessing the impact of e-marketing application on prominent exporters' performance in 2000-2005", Scientific and Research Journal of Shahed UniversityIran, year. 15, No. 32

\section{About the author and correspondence}

Napassorn Ittiprasert is MBA student majoring in Digital marketing, double degree program at University of the Thai Chamber of Commerce, (Bangkok, Thailand) and Harbour.Space, (Barcelona, Spain). Napassorn background includes strategic analyst, business development and digital marketing roles recently in Thailand. Her research interests surround marketing, innovation and financial performance, although not restricted to insurance and technology dominant sectors. For the previous experience in higher education, Napassorn is a graduate student at Chulalongkorn business school, (Bangkok, Thailand). She obtained a bachelor degree in Banking and finance.

Napassorn Ittiprasert, University of the Thai Chamber of Commerce, Bangkok, Thailand Email: pinno.itti@gmail.com 